\title{
Postnatal Development of Type I and Type II Hair Cells in the Mouse Utricle: Acquisition of Voltage-Gated Conductances and Differentiated Morphology
}

\author{
Alfons Rüsch, ${ }^{1}$ Anna Lysakowski, ${ }^{2}$ and Ruth Anne Eatock ${ }^{1}$ \\ ${ }^{1}$ The Bobby R. Alford Department of Otorhinolaryngology and Communicative Sciences, Baylor College of Medicine, \\ Houston, Texas 77030, and '2Department of Anatomy and Cell Biology, University of Illinois at Chicago, \\ Chicago, Illinois 60612
}

The type I and type II hair cells of mature amniote vestibular organs have been classified according to their afferent nerve terminals: calyx and bouton, respectively. Mature type I and type II cells also have different complements of voltage-gated channels. Type I cells alone express a delayed rectifier, $g_{K, L}$, that is activated at resting potential. We report that in mouse utricles this electrophysiological differentiation occurs during the first postnatal week. Whole-cell currents were recorded from hair cells in denervated organotypic cultures and in acutely excised epithelia. From postnatal day 1 (P1) to P3, most hair cells expressed a delayed rectifier that activated positive to resting potential and a fast inward rectifier, $g_{k 1}$. Between P4 and P8, many cells acquired the type I-specific conductance $g_{K, L}$ and/or a slow inward rectifier, $g_{h}$. By P8, the percentages of cells expressing $g_{K, L}$ and $g_{h}$ were at mature levels.
To investigate whether the electrophysiological differentiation correlated with morphological changes, we fixed utricles at different times between P0 and P28. Ultrastructural criteria were developed to classify cells when calyces were not present, as in cultures and neonatal organs. The morphological and electrophysiological differentiation followed different time courses, converging by P28. At P0, when no hair cells expressed $g_{K, L}, 33 \%$ were classified as type I by ultrastructural criteria. By P28, 60\% of hair cells in acute preparations received calyx terminals and expressed $g_{K, L}$. Data from the denervated cultures showed that neither electrophysiological nor morphological differentiation depended on ongoing innervation.

Key words: type I hair cell; calyx terminal; voltage-gated conductance; delayed rectifier; inward rectifier; inner ear development; vestibular organ; utricle
Despite increasing interest in the development of the inner ear, relatively little is known about the development of function in the sensory hair cells. Quantitative ultrastructural studies of inner ear development are also rare. Here, we combine electrophysiological and ultrastructural methods to investigate the differentiation of hair cells in the early postnatal mouse utricle, a vestibular organ that detects linear head movements and head position.

The vestibular organs of amniotes have two types of hair cells, which are classified according to the form of synaptic terminal made by afferent nerve fibers (Wersäll, 1956). Type II cells, present in all vertebrates, receive bouton terminals. Reptiles, birds, and mammals also have type I hair cells, which in mature organs are enclosed by cup-like calyx terminals (Wersäll, 1956; Wersäll and Bagger-Sjöbäck, 1974). Individual afferent fibers frequently innervate both cell types, and thus have both bouton and calyx endings (Fernández et al., 1988, 1990, 1995).

Received Jan. 14, 1998; revised June 18, 1998; accepted June 25, 1998.

This research was supported by funds from the Karim Al-Fayed Neurobiology of Hearing Laboratory and by National Institute on Deafness and Other Communication Disorders Grant DC02290. We thank A. Aubert, J. M. Goldberg, M. Saeki, and M. Vollrath for comments on this manuscript. We thank S. D. Price for technical help with electron microscopy and photography and the Electron Microscopic Facility of the Research Resources Center of the University of Illinois at Chicago for the use of equipment.

Correspondence should be addressed to Ruth Anne Eatock, Department of Otolaryngology, Baylor College of Medicine, One Baylor Plaza, Houston, TX 77030.

Dr. Rüsch's present address: Institute of Physiology and Division of Sensory Biophysics, ENT Hospital, University of Tübingen, Röntgenweg 11, D-72076, Tübingen, Germany.

Copyright (ㄷ) 1998 Society for Neuroscience $\quad 0270-6474 / 98 / 187487-15 \$ 05.00 / 0$
The unusual morphology of the type I hair cell and calyx and their relatively late appearance in evolution suggest that they play a special role in vestibular function. An obstacle to understanding this role has been the lack of a comprehensive description of what distinguishes type I from type II hair cells. In addition to the difference in afferent terminal, they have different cell shapes (Wersäll, 1956; Lysakowski and Goldberg, 1997), hair bundle geometry (Lapeyre et al., 1992; Peterson et al., 1996), and $\mathrm{K}^{+}$ conductances. Type I, but not type II, hair cells have a delayed rectifier conductance that we call $\mathrm{g}_{\mathrm{K}, \mathrm{L}}$ (Correia and Lang, 1990; Eatock et al., 1994; Rennie and Correia, 1994; Ricci et al., 1996; Rüsch and Eatock, 1996a). In many type I cells, $g_{K, L}$ is substantially activated at the resting potential, greatly reducing the input resistance (Rennie et al., 1996; Rüsch and Eatock, 1996b). The present study extends the description of differences between type I and type II hair cells.

The presence of a signature conductance, $\mathrm{g}_{\mathrm{K}, \mathrm{L}}$, in type I cells provided a tool with which to follow the electrophysiological differentiation of the two cell types. We report here that $g_{K, L}$ was not expressed in any neonatal cells but was acquired in the latter half of the first postnatal week by a subset of hair cells. Other changes occurred at the same time. We asked whether this electrophysiological differentiation was closely linked to morphological changes in the epithelium. We developed a set of ultrastructural criteria to allow classification of hair cell type when calyx endings have not yet formed or have degenerated, as in immature epithelia and denervated cultures. The morphological differentiation that we observed followed a more gradual time course than the electrophysiological changes. Both types of change occurred 
whether the hair cells developed in vivo or in cultures that were denervated before most calyces formed. Clearly, the calyx terminal, the hallmark of type I hair cells, is not required for their differentiation.

\section{MATERIALS AND METHODS}

\section{Electrophysiology}

Tissue preparation. Utricles were excised from young albino mice (ICR outbred strain) (timed pregnant females were obtained from Harlan Sprague Dawley, Indianapolis, IN). Date of birth [postnatal day 0 (P0)] in this strain is typically embryonic day 19 (E19), with E0 being the day of vaginal plug formation as determined by the animal supplier. The animals were killed by cervical dislocation and decapitated. Some utricles (acute preparations) were excised from 1- to 17-d-old mice and studied immediately. Other utricles were explanted on collagen-coated coverslips on P1 and were grown in organotypic cultures. Each culture was used for an electrophysiology experiment between 1 and $8 \mathrm{~d}$ after explantation, corresponding to $\mathrm{P} 2$ and $\mathrm{P} 9$, respectively, and was then discarded. Culturing techniques were as previously described (Rüsch and Eatock, 1996a). Cultures were maintained at $37^{\circ} \mathrm{C}$ in Minimum Essential Medium with Earle's salts (Life Technologies, Gaithersburg, MD), supplemented with heat-inactivated horse serum (1:11; Life Technologies).

In both types of preparations, the utricular nerve was cut between the epithelium and Scarpa's ganglion. The nerve fibers in the cultures presumably degenerated within hours of being cut off from their cell bodies. Degenerating terminals were seen with the light microscope in acute preparations. No nerve endings were evident in histological material of cultures fixed $3 \mathrm{~d}$ after they were made, which was the earliest stage of the cultures that was examined histologically (see Materials and Methods, Morphology). In several experiments, whole-cell recordings were obtained from hair cells isolated from adult utricular epithelia. The utricles were excised from adult mice and mechanically dissociated after a $30 \mathrm{~min}$ treatment with medium containing crude papain $(500 \mu \mathrm{g} / \mathrm{ml}$; Sigma, St. Louis, MO) and L-cysteine (300 $\mu \mathrm{g} / \mathrm{ml}$; Sigma).

Recording. The sensory epithelium of the mouse utricle was mounted in an experimental chamber on the stage of a top-focusing microscope (Axioskop FS; Zeiss, Oberkochen, Germany) and viewed with a $40 \times$ water-immersion objective with differential interference contrast optics. For recordings, a tear was made in the sensory epithelium with a micropipette (20-30 $\mu \mathrm{m}$ tip diameter), partly exposing the basolateral surfaces of hair cells. Patch pipettes were sealed onto the basolateral membranes after cleaning them with a stream of extracellular solution. All recordings ( $n=381$ hair cells) were done in whole-cell voltage-clamp mode. Recordings were obtained from hair cells from all regions of the epithelium. Recordings were occasionally obtained from cells with relatively positive resting potentials $(-32.8 \pm 4.4 \mathrm{mV}$; range, -41 to -26 ; $n=11$ ) and small voltage-dependent currents: $<500 \mathrm{pA}$ when stepped to $0 \mathrm{mV}$ from the standard holding potential of $-64 \mathrm{mV}$. These were thought to be supporting cells and were excluded from the analysis.

Patch pipettes contained $140 \mathrm{KCl} \mathrm{mm}, 0.1 \mathrm{~mm} \mathrm{CaCl}_{2}, 5 \mathrm{~mm}$ EGTA$\mathrm{KOH}, 3.5 \mathrm{mM} \mathrm{MgCl}_{2}, 2.5 \mathrm{~mm} \mathrm{Na}_{2} \mathrm{ATP}, 5 \mathrm{mM} \mathrm{HEPES}-\mathrm{KOH}, \mathrm{pH} 7.4$, and $290 \mathrm{mmol} / \mathrm{kg}$. The free $\mathrm{Ca}^{2+}$ concentration is $\sim 2 \mathrm{~nm}$ (calculated with EQCAL software; Biosoft, Cambridge, England). The experimental chamber was perfused at $10 \mathrm{ml} / \mathrm{hr}^{-1}$ with an extracellular solution that contained $144 \mathrm{~mm} \mathrm{NaCl}, 0.7 \mathrm{~mm} \mathrm{NaH}_{2} \mathrm{PO}_{4}, 5.8 \mathrm{~mm} \mathrm{KCl}, 1.3 \mathrm{~mm} \mathrm{CaCl}_{2}$, $0.9 \mathrm{~mm} \mathrm{MgCl}_{2}, 5.6 \mathrm{~mm}$ D-glucose, $10 \mathrm{~mm}$ HEPES-NaOH, vitamins and amino acids as in Eagle's MEM, pH 7.4, and $320 \mathrm{mmol} \mathrm{kg}^{-1}$. Channel blockers were dissolved in this standard extracellular solution and applied locally through a gravity-fed micropipette. To visualize flow of the superfusate, we added polystyrene latex beads (Sigma) of $\sim 1 \mu \mathrm{m}$ in diameter at a concentration of $\sim 5 \times 10^{6} \mathrm{ml}^{-1}$. Recordings were made at room temperature $\left(22-25^{\circ} \mathrm{C}\right)$.

Analysis. Series resistances $\left(\mathrm{R}_{\mathrm{s}}\right)$ and capacitances $(\mathrm{C})$ were calculated from fits of monoexponential functions to capacitive current transients evoked by $-10 \mathrm{mV}$ steps from a holding potential at which most voltagegated channels were deactivated $(-64 \mathrm{mV}$ for type II hair cells; -104 $\mathrm{mV}$ for type I hair cells). $\mathrm{R}_{\mathrm{s}}$ and $\mathrm{C}$ values were also read from the patch-clamp amplifier (Axopatch 200A; Axon Instruments, Foster City, CA) after electronically nulling the current transients. These values were usually within $10 \%$ of the values obtained by fitting the transients. $R_{s}$ was between 2.5 and $11 \mathrm{M} \Omega, 70-90 \%$ of which was electronically compensated by the amplifier. Data were filtered with an eight-pole low-pass Bessel filter (902; Frequency Devices, Haverhill, MA), with corner frequencies ranging from $500 \mathrm{~Hz}$ for experiments on the slow conduc- tances $\mathrm{g}_{\mathrm{K}, \mathrm{L}}$ and $\mathrm{g}_{\mathrm{h}}$ to $10 \mathrm{kHz}$ for capacitance measurements and experiments on the fast inward rectifier $\mathrm{g}_{\mathrm{K} 1}$. The data were digitized at twice the filter frequency using a 12-bit acquisition board (Digidata 1200; Axon Instruments) in conjunction with the software package pClamp 6.0 (Axon Instruments) and stored on disk. Voltages have been corrected off-line for liquid junction potentials $(-4 \mathrm{mV}$ for the standard solutions) and, for steady-state activation curves, uncompensated series resistances. Leak subtraction was not done unless stated. The linear leak conductance was usually $<1 \mathrm{nS}$. Analyses and fits were done with the program Origin (Microcal Software, Northampton, MA), which uses a LevenbergMarquardt least-squares fitting algorithm.

Steady-state activation (conductance-voltage) curves were generated from tail currents after steps to various membrane voltages. The tail currents were fitted, extrapolated to the offset of the iterated prepulse, and then converted to conductance by dividing by the driving force. Plots of the conductance values against the prepulse membrane potential were fitted with Boltzmann functions:

$$
\mathrm{g}=\frac{\mathrm{g}_{\max }}{1+e^{ \pm\left(V_{1 / 2}-V_{\mathrm{m}}\right) / S}}
$$

where $\mathrm{g}$ is conductance, $\mathrm{g}_{\max }$ is maximum conductance, $V_{\mathrm{m}}$ is membrane potential, $V_{1 / 2}$ is the potential at which the conductance is half-maximally activated, and $S$ is the voltage corresponding to an $e$-fold change in conductance.

Equation 2 was used to fit the sigmoidal activation kinetics of $\mathrm{g}_{\mathrm{K}, \mathrm{L}}$, $\mathrm{g}_{\mathrm{DR}, \mathrm{I}}, \mathrm{g}_{\mathrm{DR}, \mathrm{II}}, \mathrm{g}_{\mathrm{h}}$, and the sigmoidal deactivation kinetics of $\mathrm{g}_{\mathrm{h}}$.

$$
I(t)=I_{\infty}-\frac{\left(I_{\infty}-I_{0}\right)}{\tau_{1}-\tau_{2}}\left(\tau_{1} e^{-t / \tau_{1}}-\tau_{2} e^{-t / \tau_{2}}\right),
$$

where $I(t)$ is the current at time $t, I_{0}$ is the current at $0 \mathrm{msec}, I_{\infty}$ is the current in steady state, and $\tau_{1}$ and $\tau_{2}$ are macroscopic time constants that give the time course of the final approach to peak current and the sigmoidal onset, respectively.

We measured the reversal potential, $V_{\text {rev }}$, of conductances from instantaneous $I-V$ relationships. The conductance was activated by stepping to a voltage within its activation range for a fixed period and then stepping through an iterated series of voltages. The tail currents evoked by the iterated step were fitted and extrapolated back to the instant of the step. The extrapolated values were plotted against membrane potential, and reversal potentials were obtained from linear fits of the data in the vicinity of the reversal.

Data from hair cells in cultured and acute preparations were similar and have been pooled, unless stated otherwise. Results are presented as mean $\pm \mathrm{SD}$.

\section{Morphology}

To assess the postnatal morphological appearance of the utricle, we examined its ultrastructure at fixed time points and classified and counted all the cells in representative samples. Most of the data are from utricles that were fixed in situ. For comparison, several cultured epithelia were also fixed and studied. In situ fixations were performed at P0 ( $n=4$ animals), P3 $(n=1), \mathrm{P} 4(n=3), \mathrm{P} 7(n=3), \mathrm{P} 10(n=3)$, and P28 $(n=$ $2)$. Cultures were fixed $3(n=1$ culture $), 6(n=1)$, and $9(n=1) \mathrm{d}$ after they were made on P1. We refer to the cultures by the corresponding postnatal ages, P4, P7, and P10.

Fixation and post-fixation. For in situ fixations, ICR mice were first deeply anesthetized with a mixture of $10 \%$ 5-5,diallylbarbituric acid, $40 \%$ urethane, and $40 \%$ monoethyl urea $\left(0.3 \mathrm{ml} / \mathrm{kg}^{-1}\right.$, i.p. $)$ and then perfused transcardially with $2 \mathrm{ml}$ of a warm heparinized saline, $\mathrm{pH} \mathrm{7.4,}$ followed by $10 \mathrm{ml}$ of a warm trialdehyde fixative (3\% glutaraldehyde, $2 \%$ paraformaldehyde, $1 \%$ acrolein, and 5\% sucrose in $0.08 \mathrm{M}$ cacodylate buffer) (DeGroot et al., 1987). The same fixative was used to fix the cultured organs. All utricles were post-fixed for $1 \mathrm{hr}$ in $1 \% \mathrm{OsO}_{4}$ in $0.1 \mathrm{M}$ cacodylate buffer, dehydrated in graded alcohols and propylene oxide, and embedded in araldite (Durcupan; Fluka BioChemika, Ronkonkoma, NY).

Sectioning. For sectioning, the utricular epithelium was oriented perpendicular to its long axis so that sections in the middle of each block contained hair cells in each of three regions: the striola, the lateral extrastriola, and the medial extrastriola. The striola is a narrow strip of hair cells, $\sim 80 \mu \mathrm{m}$ wide in these organs, which has specialized morphology (Lindeman, 1973; Fernández et al., 1990) and afferent physiology (Goldberg et al., 1990). Glass knives were used to cut semithin serial 
A

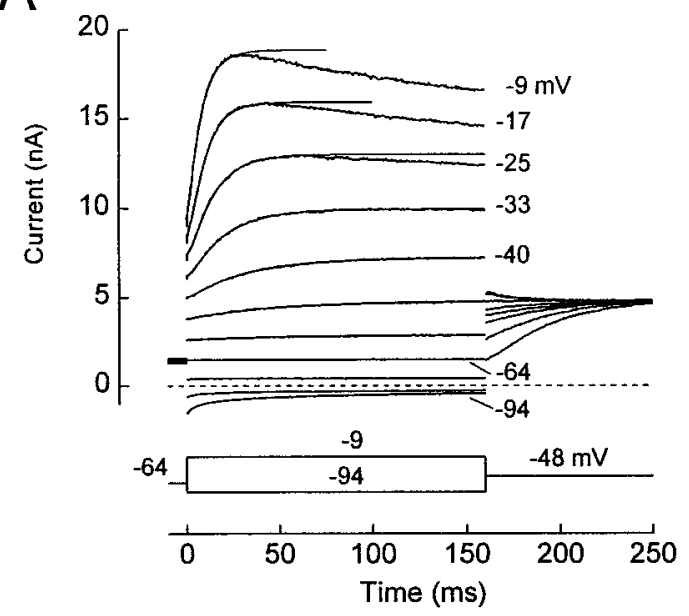

C

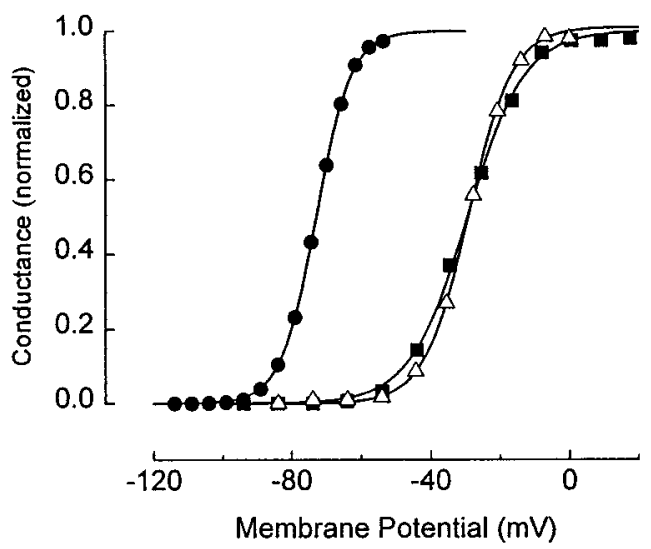

B

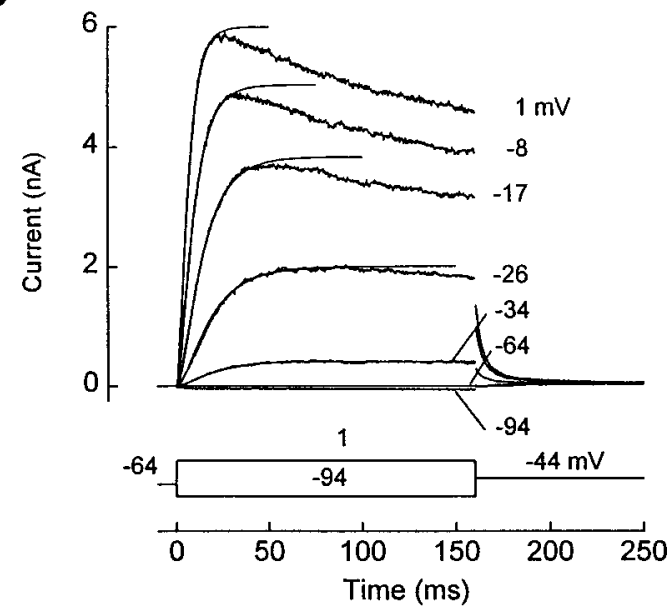

D

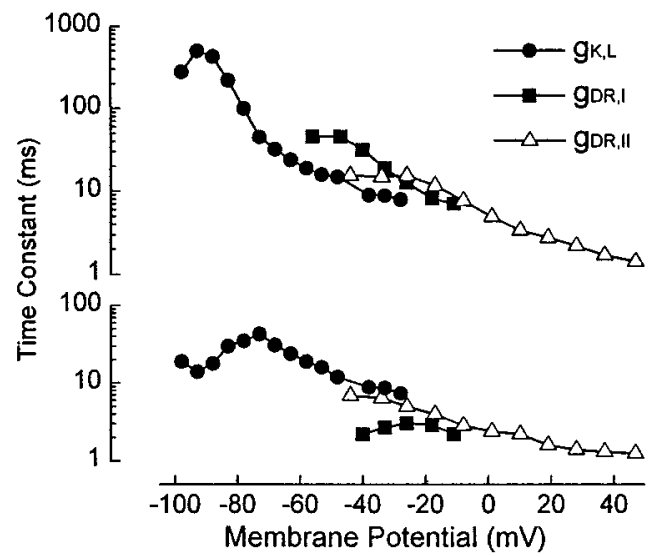

Figure 1. Delayed rectifiers $\mathrm{g}_{\mathrm{K}, \mathrm{L}}, \mathrm{g}_{\mathrm{DR}, \mathrm{I}}$, and $\mathrm{g}_{\mathrm{DR}, \mathrm{II}}$ in mouse utricular hair cells. $A, B$, Families of current traces from a cell with $\mathrm{g}_{\mathrm{K}, \mathrm{L}}(A$, acute preparation, P9) and a cell without $\mathrm{g}_{\mathrm{K}, \mathrm{L}}(B$, culture, $\mathrm{P} 4)$ in response to voltage steps from $V_{\mathrm{H}}=-64 \mathrm{mV}$. Single presentations. The voltage steps, corrected for $\mathrm{R}_{\mathrm{s}}$ error, are indicated next to most current traces. Data points between $0 \mathrm{msec}$ and the peak of each outward current trace were fitted with Equation 2 (solid lines) and then extrapolated in time, as shown. In $A$, the instantaneous currents at the onset of voltage steps and the decaying inward currents at -94 and $-84 \mathrm{mV}$ are through $\mathrm{g}_{\mathrm{K}, \mathrm{L}}$. The sigmoidally activating current positive to $-64 \mathrm{mV}$ is through $\mathrm{g}_{\mathrm{DR}, \mathrm{I}}$ in $A$ and $\mathrm{g}_{\mathrm{DR}, \mathrm{II}}$ in $B$. In $B$, the small inward current at $-94 \mathrm{mV}$ is through $\mathrm{g}_{\mathrm{K} 1}$ and $\mathrm{g}_{\mathrm{h}}$. $C$, Activation curves. Legend in $D$ applies to $C$. Data for $\mathrm{g}_{\mathrm{K}, \mathrm{L}}$ ( filled circles) are from the cell in $A$, obtained with a different protocol (below). The data for $\mathrm{g}_{\mathrm{DR}, \mathrm{I}}$ ( filled squares) were from a different cell (culture, P6); $\mathrm{g}_{\mathrm{K}, \mathrm{L}}$ was blocked by superfusing the cell with $20 \mathrm{~mm} \mathrm{Ba}^{2+}$ (Rüsch and Eatock, 1996a). The cell without $\mathrm{g}_{\mathrm{K}, \mathrm{L}}$ (open triangles) was from a culture at P7. For $\mathrm{g}_{\mathrm{DR}, \mathrm{I}}$ and $\mathrm{g}_{\mathrm{DR}, \mathrm{II}}$, the activation curves were generated with protocols similar to those in $A$ and $B$, except that $V_{\mathrm{H}}=-84 \mathrm{mV}$. For the $\mathrm{g}_{\mathrm{K}, \mathrm{L}}$ data, $V_{\mathrm{H}}=-84 \mathrm{mV}$, hyperpolarizing prepulses $(250 \mathrm{msec}$ to $-124 \mathrm{mV})$ were used to remove inactivation of $\mathrm{g}_{\mathrm{K}, \mathrm{L}}$, the iterated voltage steps were $800 \mathrm{msec}$, and tail currents were elicited at $-54 \mathrm{mV}$ to avoid activating $\mathrm{g}_{\mathrm{DR}, \mathrm{I}}$. Tail currents were fitted with double-exponential functions. Curves, Normalized fits of Equation 1 . $\mathrm{g}_{\mathrm{K}, \mathrm{L}}$ : $\mathrm{g}_{\max }=147 \mathrm{nS} ; V_{1 / 2}=-73 \mathrm{mV} ; S=5.1 \mathrm{mV}$. $\mathrm{g}_{\mathrm{DR}, \mathrm{I}}: \mathrm{g}_{\max }=28 \mathrm{nS} ; V_{1 / 2}=-29 \mathrm{mV} ; S=8.3 \mathrm{mV}$. $\mathrm{g}_{\mathrm{DR}, \mathrm{II}}: \mathrm{g}_{\max }=52.0 \mathrm{nS} ; V_{1 / 2}=-29.1 \mathrm{mV} ; S=6.4 \mathrm{mV}$. $D$, Voltage dependence of activation time constants. Time constants were obtained by fitting activating currents with Equation 2 and are shown on separate ordinates for clarity: $\tau_{1}$, top; $\tau_{2}$, bottom. The time constants for $\mathrm{g}_{\mathrm{DR}, \mathrm{I}}$ are from the fits to the current traces shown in $A$. We assumed that the sigmoidal activating currents positive to $-60 \mathrm{mV}$ were through $\mathrm{g}_{\mathrm{DR}, \mathrm{I}}$ exclusively, because $\mathrm{g}_{\mathrm{K}, \mathrm{L}}$ in this cell was fully activated at $V_{\mathrm{H}}=-64 \mathrm{mV}(C)$. The time constants for $\mathrm{g}_{\mathrm{DR}, \mathrm{II}}$ are from the fits to the current traces in $B$ and additional traces. The time constants for $\mathrm{g}_{\mathrm{K}, \mathrm{L}}$ are from a cell (acutely dissociated, $\mathrm{P} 17)$ recorded with an internal solution in which all $\mathrm{K}^{+}$was replaced with $\mathrm{Cs}^{+}$. $\mathrm{Cs}^{+}$permeates $\mathrm{g}_{\mathrm{K}, \mathrm{L}}$ but not $\mathrm{g}_{\mathrm{DR}, \mathrm{I}}$. In this cell, $\mathrm{V}_{1 / 2}$ for $\mathrm{g}_{\mathrm{K}, \mathrm{L}}$ was $-81 \mathrm{mV}$.

sections, 2 or $5 \mu \mathrm{m}$ thick, through the first one-third to one-half of a block. The sections were serially mounted on glass slides. A long series of ultrathin $(75 \mathrm{~nm})$ serial sections was then cut from the middle of the block with a diamond knife (Delaware Diamond Knives, Wilmington, DE). From each series, 1-2 sets of 32 consecutive sections were chosen. Each set formed a sample $\sim 2.4 \mu \mathrm{m}$ thick. Two or three samples (1 or 2 per animal) were obtained at each postnatal stage. Semithin sections were cut from the remainder of the block. The semithin sections from either side of the ultrathin section series were examined in the light microscope and were used to reconstruct the location of the ultrathin samples.

Ribbons of sections were stained with uranyl acetate and lead citrate (Reynolds, 1963) and examined in a JEOL 100S electron microscope.
Micrographs were taken of every fifth ultrathin section (375 $\mathrm{nm}$ apart), and a photomontage $(5,000 \times$ final magnification) was made of the entire epithelium contained in the section. The hair cells of each sample, covered by eight such photomontages, were classified as described below, and then cells in each class were counted by their corresponding nuclei. To avoid double counting, we used the dissector method (Gundersen, 1986) as described in detail elsewhere (Fernández et al., 1995; Lysakowski and Goldberg, 1997).

For epithelia that were fixed in situ, counts were performed on three samples from two animals each at P0, P4, P7, and P10, and on two samples from one animal at P28. The same techniques were applied to one sample each from cultured epithelia at P4, P7, and P10.

Cell classification. We classified each cell in a sample as a supporting 

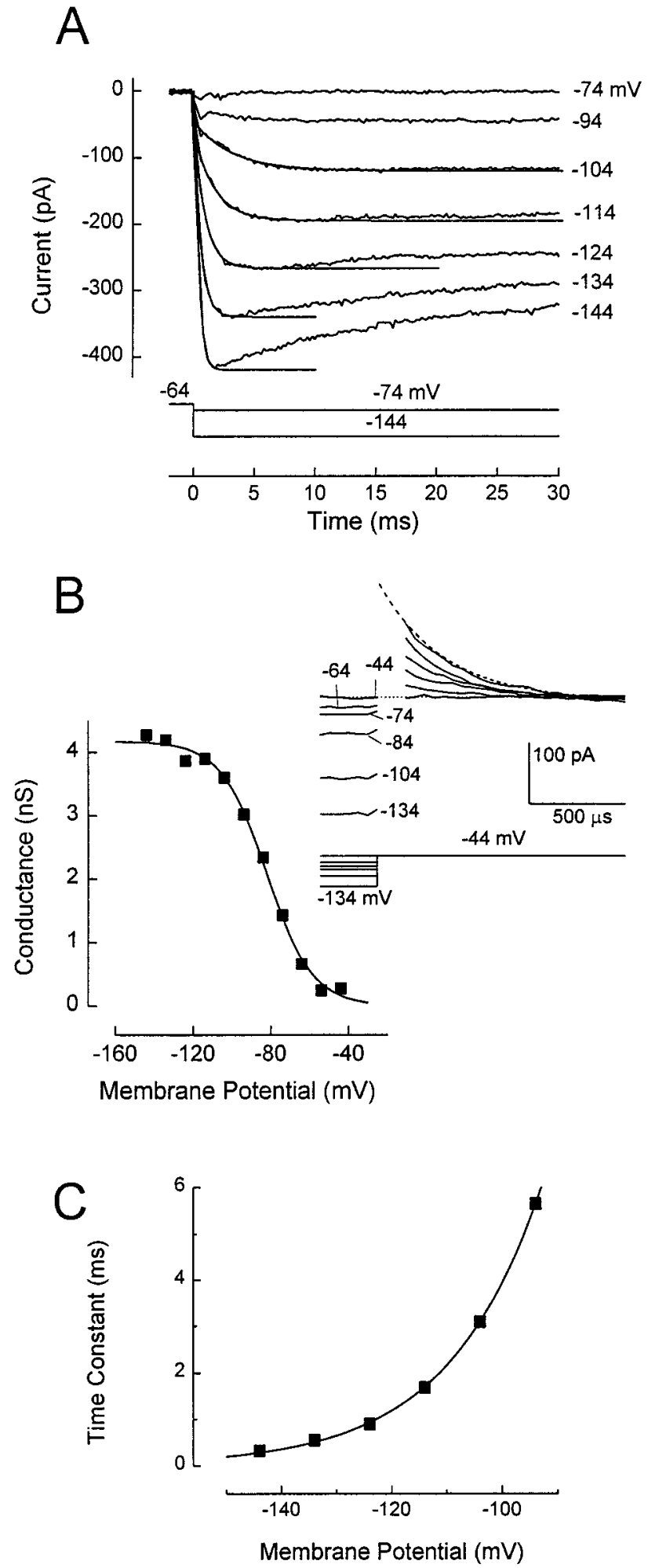

Figure 2. The fast inwardly rectifying conductance $\mathrm{g}_{\mathrm{K} 1}$. $A$, Family of current traces elicited by steps from $V_{\mathrm{H}}=-64 \mathrm{mV}$ to potentials shown to the right of the traces. Traces from -144 to $-104 \mathrm{mV}$ are overlaid by single-exponential fits to the data points between $0 \mathrm{msec}$ and the time of the peak current. Cell without $\mathrm{g}_{\mathrm{K}, \mathrm{L}}$ or $\mathrm{g}_{\mathrm{h}}$, culture, P3. B, Activation curve. Data from a different cell without $\mathrm{g}_{\mathrm{K}, \mathrm{L}}$ or $\mathrm{g}_{\mathrm{h}}$, culture, P5. Solid line, A fit of Equation 1. $\mathrm{g}_{\max }=4.2 \mathrm{nS} ; V_{1 / 2}=-82 \mathrm{mV} ; S=11.6 \mathrm{mV}$. This was not corrected for a linear leak conductance of $200 \mathrm{pS}$, measured at $V_{\mathrm{H}}=-84$ $\mathrm{mV}$ after blocking $\mathrm{g}_{\mathrm{K} 1}$ with $1 \mathrm{mM}\left[\mathrm{Cs}^{+}\right]_{\mathrm{o}}$. Inset, Some of the tail current traces used to construct the activation curve. Tail currents were elicited at cell or one of several types of hair cell: immature hair cell, type I hair cell, type II hair cell, and undefined hair cell. The criteria used to classify cell type are described in Results.

\section{RESULTS}

\section{Electrophysiology}

Delayed rectifiers

Figure 1, $A$ and $B$, shows whole-cell current families evoked by our standard voltage protocol in two hair cells. The data were chosen to illustrate the two main types of outward currents that we encountered. In $A$, there was an outward current at the holding potential $\left(V_{\mathrm{H}}=-64 \mathrm{mV}\right)$ and instantaneous jumps in current at the onset of the voltage steps. The onset current reversed between -74 and $-84 \mathrm{mV}$ and showed some decay during steps to -84 and $-94 \mathrm{mV}$. This current was through a large $\mathrm{K}^{+}$-selective conductance, $\mathrm{g}_{\mathrm{K}, \mathrm{L}}$, which was activated at -64 $\mathrm{mV}$ and which deactivated at more negative potentials. In contrast, the cell in Figure $1 B$ had negligible current at $-64 \mathrm{mV}$ and very little onset current at the start of voltage steps. This cell did not express $\mathrm{g}_{\mathrm{K}, \mathrm{L}}$. We used input conductance at $-64 \mathrm{mV}$ $\left(\mathrm{g}_{\text {in }(-64)}\right)$ as a marker of $\mathrm{g}_{\mathrm{K}, \mathrm{L}} ; 162$ cells with $\mathrm{g}_{\mathrm{in}(-64)}>20 \mathrm{nS}$ and resting potentials negative to $-50 \mathrm{mV}$ had $\mathrm{g}_{\mathrm{K}, \mathrm{L}}$, and 198 cells with $\mathrm{g}_{\text {in }(-64)}<4 \mathrm{nS}$ did not have $\mathrm{g}_{\mathrm{K}, \mathrm{L}}$. Thirty-six cells with intermediate input conductances were excluded from analysis.

In mature inner ear organs, including the mouse utricle (Eatock et al., 1994; Ricci et al., 1996; Rüsch and Eatock, 1996a), most hair cells with $\mathrm{g}_{\mathrm{K}, \mathrm{L}}$ are type I cells, and most hair cells without $g_{K, L}$ are type II cells. As will be shown, however, a cell without $g_{K, L}$ in a young mouse utricle may be either a type II cell or an immature type I cell. For this reason, we often refer to "cells with $g_{K, L}$ " and "cells without $g_{K, L}$ " rather than type I and type II cells. Cells with and without $\mathrm{g}_{\mathrm{K}, \mathrm{L}}$ had similar mean membrane capacitances: $3.5 \pm 0.7 \mathrm{pF}(n=82$ cells $)$ and $3.6 \pm 0.9$ $\mathrm{pF}\left(n=126\right.$ cells), respectively. $\mathrm{g}_{\mathrm{K}, \mathrm{L}}$ was associated with significantly more negative resting potentials $\left(V_{\mathrm{R}}\right):-66 \pm 5.3 \mathrm{mV}$ in 158 cells without $g_{\mathrm{K}, \mathrm{L}}$ and $-77 \pm 3.7 \mathrm{mV}$ in 86 cells with $\mathrm{g}_{\mathrm{K}, \mathrm{L}}$. ( $V_{\mathrm{R}}$ values positive to $-40 \mathrm{mV}$ were excluded.) The properties of $\mathrm{g}_{\mathrm{K}, \mathrm{L}}$ are summarized in the next section.

In both cells in Figure 1, $A$ and $B$, outward currents activated sigmoidally in response to steps positive to $-64 \mathrm{mV}$. These currents were unaffected by removal of external $\mathrm{Ca}^{2+}$ (Rüsch and Eatock, 1996a) and had the kinetics of delayed rectifiers rather than A currents. We call the conductance $\mathrm{g}_{\mathrm{DR}, \mathrm{I}}$ in type I cells, $\mathrm{g}_{\mathrm{DR}, \mathrm{II}}$ in type II cells, and $\mathrm{g}_{\mathrm{DR}, \mathrm{N}}$ in neonatal cells (P1-P3).

$g_{K, L}$. In a previous report on the same preparation (Rüsch and Eatock, 1996a), we showed that $\mathrm{g}_{\mathrm{K}, \mathrm{L}}$ is $\mathrm{K}^{+}$selective and is not sensitive to removal of external $\mathrm{Ca}^{2+}$. It activates with slow sigmoidal kinetics [principle time constant $\left(\tau_{1}\right)$ at $-90 \mathrm{mV}$ was $608 \pm 233 \mathrm{msec} ; n=4$ ] (Fig. $1 D$ ) and inactivates slowly. It therefore falls into the broad class of delayed rectifiers. Compared with most delayed rectifiers, however, $\mathrm{g}_{\mathrm{K}, \mathrm{L}}$ has more $\mathrm{Cs}^{+}$ permeability and an unusually negative and variable voltage range of activation. A conductance-voltage (activation) curve is shown

\footnotetext{
$-44 \mathrm{mV}$, near the reversal potential of $\mathrm{g}_{\mathrm{h}}$. The last $300 \mu \mathrm{sec}$ of the 40 msec activating voltage steps are shown. Uncompensated capacitive currents during the first $150 \mu \mathrm{sec}$ after the step to $-44 \mathrm{mV}$ are not shown. Tail currents were fitted by single-exponential functions and extrapolated back to the instant of the step to $-44 \mathrm{mV}$; the fit is shown for the -134 $\mathrm{mV}$ trace (dashed line). $C$, Voltage dependence of the activation time constants from the fits in $A$. Solid line, A fit to the data of the following equation: $\tau=0.1+\left(4.1 \times \exp \left(V_{\mathrm{m}} / 15.5\right)\right) . \tau$ is in $\mathrm{msec}$ and $V_{\mathrm{m}}$ is in $\mathrm{mV}$.
} 


\begin{tabular}{|c|c|c|c|c|c|c|}
\hline Conductance & $\mathrm{V}_{1 / 2}, \mathrm{mV}$ & $\mathrm{S}, \mathrm{mV}$ & $\mathrm{g}_{\max }, \mathrm{nS}$ & $\mathrm{V}_{\mathrm{rev}}, \mathrm{mV}\left(E_{\mathrm{K}}=-84 \mathrm{mV}\right)$ & $K_{\mathrm{D}}(4-\mathrm{AP}), \mathrm{mM}$ & $K_{\mathrm{D}}\left(B \mathrm{a}^{2+}\right), \mathrm{mM}$ \\
\hline \multicolumn{7}{|c|}{ Delayed Rectifiers } \\
\hline $\mathrm{g}_{\mathrm{K}, \mathrm{L}}$ & -88 to $-62(57)$ & $5.4 \pm 1.4(57)$ & $73 \pm 42(78)$ & $-80.8 \pm 1.7(7)$ & 43 & 2 \\
\hline $\mathrm{g}_{\mathrm{DR}, \mathrm{I}}$ & $-25.0 \pm 6.0(3)$ & $7.7 \pm 1.0(3)$ & $114 \pm 61(78)$ & $-72.0 \pm 3.0(2)$ & 1000 & 50 \\
\hline $\mathrm{g}_{\mathrm{DR}, \mathrm{II}}$ & $-30.9 \pm 2.6(28)$ & $5.9 \pm 1.5(28)$ & $41 \pm 23(40)$ & $-73.7 \pm 1.5(6)$ & 80 & 6.5 \\
\hline $\mathrm{g}_{\mathrm{DR}, \mathrm{N}}$ & $-31.6 \pm 2.2(5)$ & $7.6 \pm 1.0(5)$ & $34 \pm 18(5)$ & & & \\
\hline \multicolumn{7}{|c|}{ Inward rectifiers } \\
\hline $\mathrm{g}_{\mathrm{K} 1}$ & $-87.9 \pm 5.3(5)$ & $9.9 \pm 2.8(5)$ & $3.6 \pm 1.7(107)$ & $-81.9 \pm 2.9(5)$ & & \\
\hline $\mathrm{g}_{\mathrm{h}}$ & $-101.0 \pm 5.0(8)$ & $7.8 \pm 1.2(8)$ & $\begin{array}{l}1.3 \pm 1.0 \mathrm{nS}\left(36 \text { with } \mathrm{g}_{\mathrm{K}, \mathrm{L}}\right) \\
1.0 \pm 0.9 \mathrm{nS}\left(79 \text { without } \mathrm{g}_{\mathrm{K}, \mathrm{L}}\right)\end{array}$ & $-43.5 \pm 1.8(5)$ & & \\
\hline
\end{tabular}

Values are mean \pm SD, unless otherwise indicated. Numbers of cells are given in parentheses.

in Figure $1 C$, fitted with a Boltzmann function (Eq. 1). $V_{1 / 2}$ values ranged from -88 to $-62 \mathrm{mV}$ (Fig. $1 C$; Table 1). More positive $V_{1 / 2}$ values may occur but are difficult to measure because of interference by $\mathrm{g}_{\mathrm{DR}, \mathrm{I}}$.

The mean maximum $\mathrm{g}_{\mathrm{K}, \mathrm{L}}$ was $\sim 75 \mathrm{nS}$ (Table 1 ), which is very large for the small size of these cells. The presence of a large conductance that is substantially activated at $V_{\mathrm{R}}$ drastically reduces the input resistance and therefore the size of voltage responses to injected currents (Rüsch and Eatock, 1996b).

$g_{D R, I}$ and $g_{D R, I I}$. Activation curves of $\mathrm{g}_{\mathrm{DR}, \mathrm{I}}$ and $\mathrm{g}_{\mathrm{DR}, \mathrm{II}}$ are shown in Figure $1 C$. Fits by a Boltzmann function (Eq. 1) to the two conductances produced similar $V_{1 / 2}$ values (between -25 and $-30 \mathrm{mV}$ ) and $S$ values $(6-8 \mathrm{mV})$ (Table 1$)$. Activation curves for $\mathrm{g}_{\mathrm{DR}, \mathrm{N}}$ in neonatal cells had similar values (Table 1). Variation in $V_{1 / 2}$ values was much lower for these conductances than for $\mathrm{g}_{\mathrm{K}, \mathrm{L}}$.

The time courses of activation of $\mathrm{g}_{\mathrm{DR}, \mathrm{I}}$ and $\mathrm{g}_{\mathrm{DR}, \mathrm{II}}$ were well described by Equation 2, as shown by the fits in Figure 1, $A$ and $B$. Figure $1 D$ shows the fast and slow time constants from these fits and fits of the same equation to currents through $g_{K, L} \cdot g_{K, L}$ was slowest, and $g_{D R, I}$ was slower than $g_{D R, I I}$. The principal (slow) time constant $\left(\tau_{1}\right)$ at $-44 \mathrm{mV}$ was $44.2 \pm 8.3 \mathrm{msec}(n=4$ cells) for $\mathrm{g}_{\mathrm{DR}, \mathrm{I}}$ and $17.1 \pm 6.9 \mathrm{msec}$ for $\mathrm{g}_{\mathrm{DR}, \mathrm{II}}(n=4$ cells at P7 or later) $(0.01<p<0.05$, Student's $t$ test $)$.

$\mathrm{g}_{\mathrm{DR}, \mathrm{I}}$ and $\mathrm{g}_{\mathrm{DR}, \mathrm{II}}$ were $\mathrm{K}^{+}$selective, as shown by the proximity of their reversal potentials (approximately $-73 \mathrm{mV}$ ) (Table 1) to $E_{\mathrm{K}}$. The value for $\mathrm{g}_{\mathrm{DR}, \mathrm{I}}$ was obtained after blocking $\mathrm{g}_{\mathrm{K}, \mathrm{L}}$ with $5 \mathrm{~mm}$ 4-AP.

We tested the sensitivity of $\mathrm{g}_{\mathrm{DR}, \mathrm{II}}$ to 4 -AP and external $\mathrm{Ba}^{2+}$ for comparison with values reported previously for $\mathrm{g}_{\mathrm{DR}, \mathrm{I}}$ and $\mathrm{g}_{\mathrm{K}, \mathrm{L}}$ (Rüsch and Eatock, 1996a). Cells were held at $-64 \mathrm{mV}$, and currents were activated by $160 \mathrm{msec}$ voltage steps to $0 \mathrm{mV}$ before and during superfusion with the blocker. Steady-state current at $0 \mathrm{mV}$ in the presence of a given concentration of the blocker, $[B]$, was expressed as the fraction, $f$, of the current in control conditions. The dissociation constant was calculated as $K_{\mathrm{D}}=([B])$ $(f /(1-f))$. Concentrations tested were $5 \mathrm{~mm}$ for $\mathrm{Ba}^{2+}$ and between 10 and $100 \mu \mathrm{M}$ for 4-AP. The estimated $K_{\mathrm{D}}$ values are an order of magnitude lower than those for $\mathrm{g}_{\mathrm{DR}, \mathrm{I}}$ (Table 1).

The maximum size of $\mathrm{g}_{\mathrm{DR}, \mathrm{II}}$ (see Fig. $4 D$; Table 1) was obtained from Boltzmann fits of activation curves at $-44 \mathrm{mV}\left(\mathrm{g}_{\max }\right.$ in Eq. 1) for 40 cells between P1 and P17. Estimating maximum $\mathrm{g}_{\mathrm{DR}, \mathrm{I}}$ was more difficult, because $\mathrm{g}_{\mathrm{K}, \mathrm{L}}$ was maximally activated at voltages at which $\mathrm{g}_{\mathrm{DR}, \mathrm{I}}$ was maximally activated (Fig. $1 C$ ). We estimated maximum $\mathrm{g}_{\mathrm{DR}, \mathrm{I}}$ as follows. We measured whole-cell current at $-54 \mathrm{mV}$, at which it is mostly through $\mathrm{g}_{\mathrm{K}, \mathrm{L}}$, and at 0 $\mathrm{mV}$, at which it is mostly through $\mathrm{g}_{\mathrm{K}, \mathrm{L}}$ and $\mathrm{g}_{\mathrm{DR}, \mathrm{I}}$. To estimate $\mathrm{g}_{\mathrm{K}, \mathrm{L}}$ at $0 \mathrm{mV}$, we assumed that $\mathrm{g}_{\mathrm{K}, \mathrm{L}}$ is maximally activated at $-54 \mathrm{mV}$ and that its $I-V$ relationship is linear between -54 and $0 \mathrm{mV}$. We extrapolated the current through $\mathrm{g}_{\mathrm{K}, \mathrm{L}}$ at $0 \mathrm{mV}$ from its value at $-54 \mathrm{mV}$ and subtracted the result from the total current at $0 \mathrm{mV}$, giving the current through $\mathrm{g}_{\mathrm{DR}, \mathrm{I}}$.

The mean maximal $g_{D R, I}$ significantly exceeded the mean maximal $g_{K, L}$ measured from the same cells and was more than twice as large as the mean maximal $g_{D R, I I}$ (Table 1). The sum of the delayed rectifier conductances in type I cells often exceeded 200 $\mathrm{nS}$. In the mouse utricle, type I and type II cells have similar membrane capacitances and therefore surface areas, so that the larger conductances of type I cells reflect higher current densities. Summing the mean maximal $\mathrm{g}_{\mathrm{K}, \mathrm{L}}$ and $\mathrm{g}_{\mathrm{DR}, \mathrm{I}}$ values and dividing by the mean capacitance gives $\sim 50 \mathrm{nS} / \mathrm{pF}$, approximately fivefold higher than the specific conductances of mouse cochlear inner hair cells (Kros and Crawford, 1990), turtle cochlear hair cells (Wu et al., 1995), and CA1 neurons from the hippocampus (Klee et al., 1995).

\section{Inward rectifiers}

Hyperpolarizing steps from $V_{\mathrm{H}}=-64 \mathrm{mV}$ activated fast and slow inward currents that could be isolated pharmacologically. The fast component was fully blocked by $1 \mathrm{~mm}$ external $\mathrm{Ba}^{2+}$, leaving the slow component primarily unscathed. The slow component was blocked by $1 \mathrm{~mm}$ external $\mathrm{Cd}^{2+}$, leaving just the fast component. Both components were blocked by $1 \mathrm{~mm}$ external $\mathrm{Cs}^{+}$. This pharmacology and the other properties described below show that the fast and slow components correspond to the two inward rectifiers $g_{\mathrm{K} 1}$ and $\mathrm{g}_{\mathrm{h}}$, described in other hair cells (Fuchs and Evans, 1990; Holt and Eatock, 1995; Goodman and Art, 1996; Sugihara and Furukawa, 1996).

$g_{K 1}$. Figure $2 A$ shows a family of $\mathrm{g}_{\mathrm{K} 1}$ currents activated by hyperpolarizing steps from $V_{\mathrm{H}}=-64 \mathrm{mV}$ in a cell with neither $\mathrm{g}_{\mathrm{h}}$ nor $\mathrm{g}_{\mathrm{K}, \mathrm{L}}$. The reversal potential $(-82 \mathrm{mV})$ (Table 1$)$ was close to $E_{\mathrm{K}}$, showing that $\mathrm{g}_{\mathrm{K} 1}$ was highly $\mathrm{K}^{+}$selective. The gating of the $\mathrm{g}_{\mathrm{K} 1}$ family of inward rectifiers shifts with $E_{\mathrm{K}}$ (Hagiwara et al., 1976). In our solutions $\left(E_{\mathrm{K}}=-84 \mathrm{mV}\right), \mathrm{g}_{\mathrm{K} 1}$ activated negative to $-40 \mathrm{mV}$ and was almost completely activated at $-120 \mathrm{mV}$ (Fig. $2 B$; Table 1).

$\mathrm{g}_{\mathrm{K} 1}$ activated with single-exponential kinetics (Fig. $2 A$ ). At $-100 \mathrm{mV}$, the time constant of activation was $\sim 4 \mathrm{msec}$ and decreased $e$-fold with $15.5 \mathrm{mV}$ of hyperpolarization (Fig. 2C). Positive to $-110 \mathrm{mV}, \mathrm{g}_{\mathrm{K} 1}$ did not inactivate. Inactivation at more negative potentials may reflect block by $\mathrm{Na}^{+}$(Ohmori, 1984).

$\mathrm{g}_{\max }(\sim 4 \mathrm{nS})$ (Table 1) was estimated from the current 3-5 msec after the onset of a step to $-124 \mathrm{mV}$. This method did not eliminate leak conductances, which were between 0.1 and $1.5 \mathrm{nS}$. $g_{h}$. In frog saccular hair cells (Holt and Eatock, 1995), $\mathrm{g}_{\mathrm{h}}$ 
contributes to the input conductance and resting potential and causes a transient voltage response to hyperpolarizing current steps. The latter effect is also seen in mouse utricular hair cells (Rüsch and Eatock, 1996b). The activation and kinetic properties of $g_{\mathrm{h}}$ in the mouse utricle also resemble those in the frog saccule. Figure $3 A$ shows current through $\mathrm{g}_{\mathrm{h}}$ activated by hyperpolarizing steps from $-64 \mathrm{mV} . \mathrm{g}_{\mathrm{h}}$ started to activate near the mean resting potential of cells without $\mathrm{g}_{\mathrm{K}, \mathrm{L}}(-67 \mathrm{mV})$ and was fully activated by $-140 \mathrm{mV}$ (Fig. 3B).

$\mathrm{g}_{\mathrm{h}}$ activated and deactivated with sigmoidal kinetics, which were fit by Equation 2 (Fig. $3 A$ ). The two activation time constants reached maximal values of $\sim 220$ and $30 \mathrm{msec}$ close to -98 $\mathrm{mV}$, at which $\mathrm{g}_{\mathrm{h}}$ was half-activated (Fig. $3 B$ ). $\mathrm{g}_{\mathrm{h}}$ did not inactivate within $500 \mathrm{msec}$ (data not shown) at any membrane potential. $\mathrm{g}_{\mathrm{h}}$ also had sigmoidal deactivation kinetics in frog saccular hair cells.

To measure maximal $g_{h}$ in a large number of cells, we took the current evoked by a step from $-64 \mathrm{mV}$ to $-124 \mathrm{mV}$ and subtracted the current at $10 \mathrm{msec}$ from the current at $400 \mathrm{msec}$. At 10 msec, the current through $\mathrm{g}_{\mathrm{h}}$ is not substantially activated (principal $\tau$ of $\sim 60 \mathrm{msec}$ at $-124 \mathrm{mV}$ ) (Fig. $3 C$ ), but currents flowing through the linear leak conductance and $\mathrm{g}_{\mathrm{K} 1}$ have reached steady state. Therefore, the difference current is exclusively through $\mathrm{g}_{\mathrm{h}}$. The mean conductance $(\sim 1 \mathrm{nS})$ (Table 1$)$ was similar for cells with and without $\mathrm{g}_{\mathrm{K}, \mathrm{L}}$.

The reversal potential of $g_{h}$ (approximately $-44 \mathrm{mV}$ ) (Table 1 ) was measured in five cells that lacked $g_{\mathrm{K}, \mathrm{L}}$ and in which $\mathrm{g}_{\mathrm{K} 1}$ was blocked with $1 \mathrm{~mm}$ external $\mathrm{Ba}^{2+}$. If we assume that the current is carried just by $\mathrm{K}^{+}$and $\mathrm{Na}^{+}$, we calculate from the reversal potential a permeability coefficient $\left(P_{\mathrm{Na}} / P_{\mathrm{K}}\right)$ of 0.14 , similar to the value for $g_{\mathrm{h}}$ in other hair cells (Holt and Eatock, 1995; Sugihara and Furukawa, 1996).

\section{Changes with postnatal age}

On P1-P2, hair cells in the mouse utricle expressed $g_{D R, N}$ and $g_{K 1}$ but neither $\mathrm{g}_{\mathrm{K}, \mathrm{L}}$ nor $\mathrm{g}_{\mathrm{h}}$. The first cell with $\mathrm{g}_{\mathrm{K}, \mathrm{L}}$ was encountered in a cultured epithelium on $\mathrm{P} 3$ (Fig. $4 A$ ), after which the percentage of cells with $g_{\mathrm{K}, \mathrm{L}}$ increased rapidly to a plateau of $50-75 \%$ by P6. The progression in acute preparations (Fig. 4B) was comparable but noisier, presumably reflecting the smaller numbers of measurements per day. When data obtained after P7 were pooled, similar percentages of cells expressed $g_{\mathrm{K}, \mathrm{L}}$ in the cultures $(70 \%)$ and in the acute preparations $(63 \%)$. The postnatal mouse utricle is primarily postmitotic (Ruben, 1967), so the change represents differentiation of cells present at birth rather than birth of a new cell type.

In Figure 4, $C$ and $D$, the fully activated conductances ( $\left.\mathrm{g}_{\max }\right)$ for $\mathrm{g}_{\mathrm{K}, \mathrm{L}}$ (Fig. $4 C$ ), $\mathrm{g}_{\mathrm{DR}, \mathrm{I}}$, and $\mathrm{g}_{\mathrm{DR}, \mathrm{II}}$ (Fig. $4 D$ ) are plotted against postnatal day. $g_{\max }$ values did not vary systematically with age. At all ages, $g_{D R, I}$ exceeded $g_{D R, I I}$. The relationships between $g_{D R, I}$, $\mathrm{g}_{\mathrm{DR}, \mathrm{II}}$, and the delayed rectifiers in the neonatal cells are not known. However, cells that acquired $g_{K, L}$ simultaneously experienced a large increase in the non- $\mathrm{g}_{\mathrm{K}, \mathrm{L}}$ delayed rectifier $\left(\mathrm{g}_{\mathrm{DR}, \mathrm{I}}\right)$. Recall that cells with $g_{\mathrm{K}, \mathrm{L}}$ have similar membrane capacitances (surface areas) to those without $\mathrm{g}_{\mathrm{K}, \mathrm{L}}$. Moreover, capacitance did not change significantly in comparisons of data from P0, P4, P7, $\mathrm{P} 10$, and P17. Thus, current density increased dramatically in type I cells relative to neonatal and type II cells.

At all stages examined, most hair cells that did not express $g_{\mathrm{K}, \mathrm{L}}$ did express $g_{\mathrm{K} 1}$ (Fig. 5). Neither the incidence nor size of $g_{K 1}$ varied systematically with postnatal age. The fate of $g_{K 1}$ in type I cells is less clear. Most cells that acquired $\mathrm{g}_{\mathrm{K}, \mathrm{L}}$ must have expressed $\mathrm{g}_{\mathrm{K} 1}$ between P1 and P3 (Fig. $5 A$ ), because the epithelium
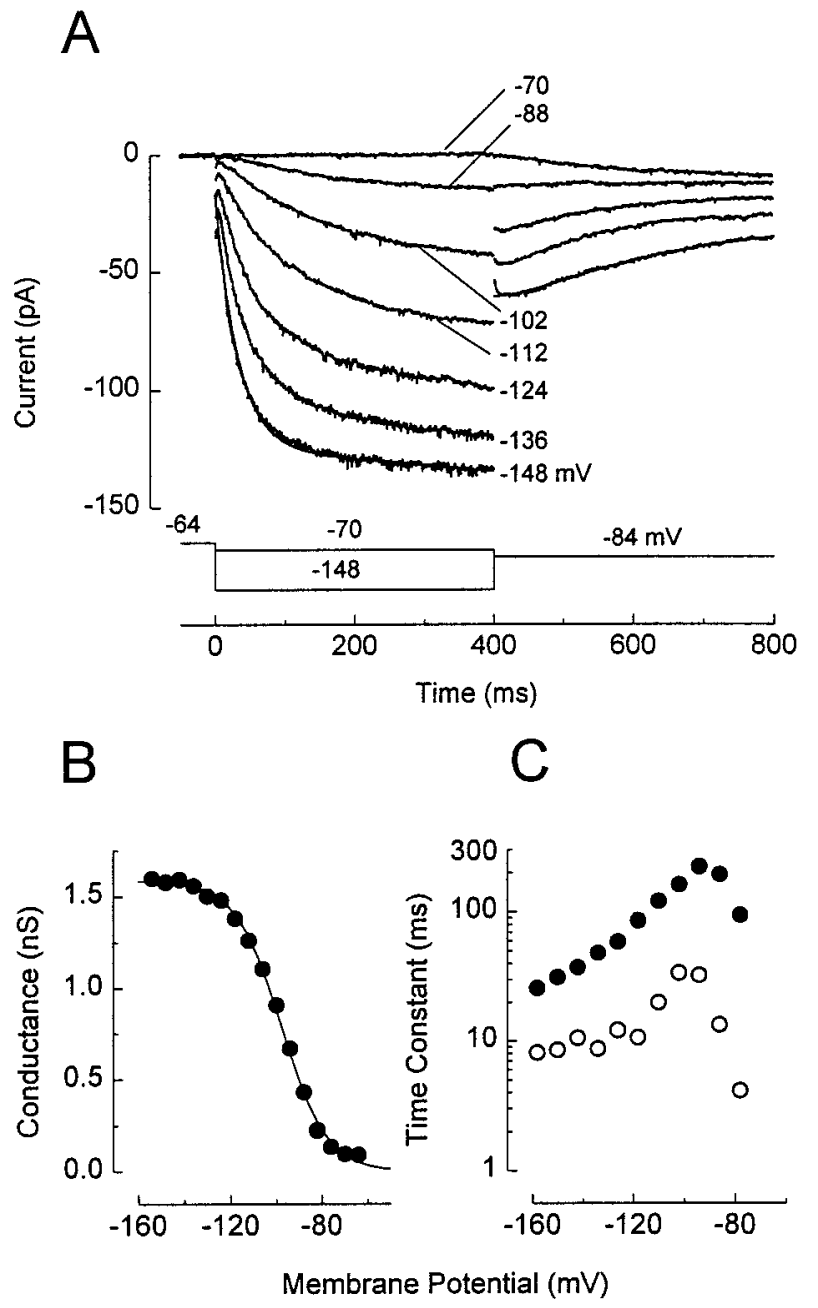

Figure 3. The slow inwardly rectifying conductance $\mathrm{g}_{\mathrm{h}}$. $A$, Family of current traces elicited by the voltage protocol shown. $V_{\mathrm{H}}=-64 \mathrm{mV}$. Cell without $\mathrm{g}_{\mathrm{K}, \mathrm{L}}$ and with $\mathrm{g}_{\mathrm{K} 1}$, culture, P5. Current through $\mathrm{g}_{\mathrm{K} 1}$ was completely blocked by $1 \mathrm{~mm}\left[\mathrm{Ba}^{2+}\right]_{\mathrm{o}}$, except for small transients at the onset of the voltage steps. Average of three presentations is shown. Tail currents were elicited at $-84 \mathrm{mV}$, close to the reversal potential of $\mathrm{g}_{\mathrm{K} 1}$. Currents during the steps to $-84 \mathrm{mV}$ are not shown. The currents in response to the voltage steps activated and deactivated with sigmoidal time courses that were fitted with Equation 2. Examples of the fits for both activation and deactivation are shown for the current trace at $-148 \mathrm{mV}$ as smooth lines superimposed on the data. Tail currents after steps to -124 and $-136 \mathrm{mV}$ were omitted for clarity. Parameters of the fit to current activation: $I_{0}=-17 \mathrm{pA} ; I_{\infty}=-125 \mathrm{pA} ; \tau_{1}=32 \mathrm{msec}$; $\tau_{2}=0.19 \mathrm{msec}$. A small linear component $(-24.8 \mathrm{fA} / \mathrm{msec})$ was added to improve the fit. Parameters of the fit to the tail current: $I_{0}=-60 \mathrm{pA}$; $I_{\infty}=-27 \mathrm{pA} ; \tau_{1}=237 \mathrm{msec} ; \tau_{2}=50 \mathrm{msec}$. Corrected for $160 \mathrm{pS}$ linear leak conductance, measured in $1 \mathrm{~mm}\left[\mathrm{Ba}^{2+}\right]_{\mathrm{o}} . B$, Activation curve. Data were measured from the tail currents at $-84 \mathrm{mV}$ shown in $A$ and additional traces. Tail currents were fitted with Equation 2, as shown for one trace in $A$, extrapolated to the instant of the step to $-84 \mathrm{mV}$, converted to conductance (assuming $V_{\text {rev }}=-43.5 \mathrm{mV}$ ), and plotted against the prepulse potential. Solid line, A fit of Equation 1. $\mathrm{g}_{\max }=1.6$ $\mathrm{nS} ; V_{1 / 2}=-98 \mathrm{mV} ; S=9.9 \mathrm{mV}$. C, Time constants of fits to the activation of currents through $\mathrm{g}_{\mathrm{h}} . \tau_{1}$, filled circles; $\tau_{2}$, open circles. Recordings in standard $\left(\mathrm{Ba}^{2+}\right.$-free) extracellular solution from a different cell with $\mathrm{g}_{\mathrm{K} 1}$ but no $\mathrm{g}_{\mathrm{K}, \mathrm{L}}$ (culture, P8). No additional linear component was used for the fits. Because $\mathrm{g}_{\mathrm{K} 1}$ activation (Fig. $2 A, C$ ) was 10 -fold faster at all potentials than the fast component of $\mathrm{g}_{\mathrm{h}}, \mathrm{g}_{\mathrm{K} 1}$ was accommodated in these fits by $I_{0}$ of Equation 2. 

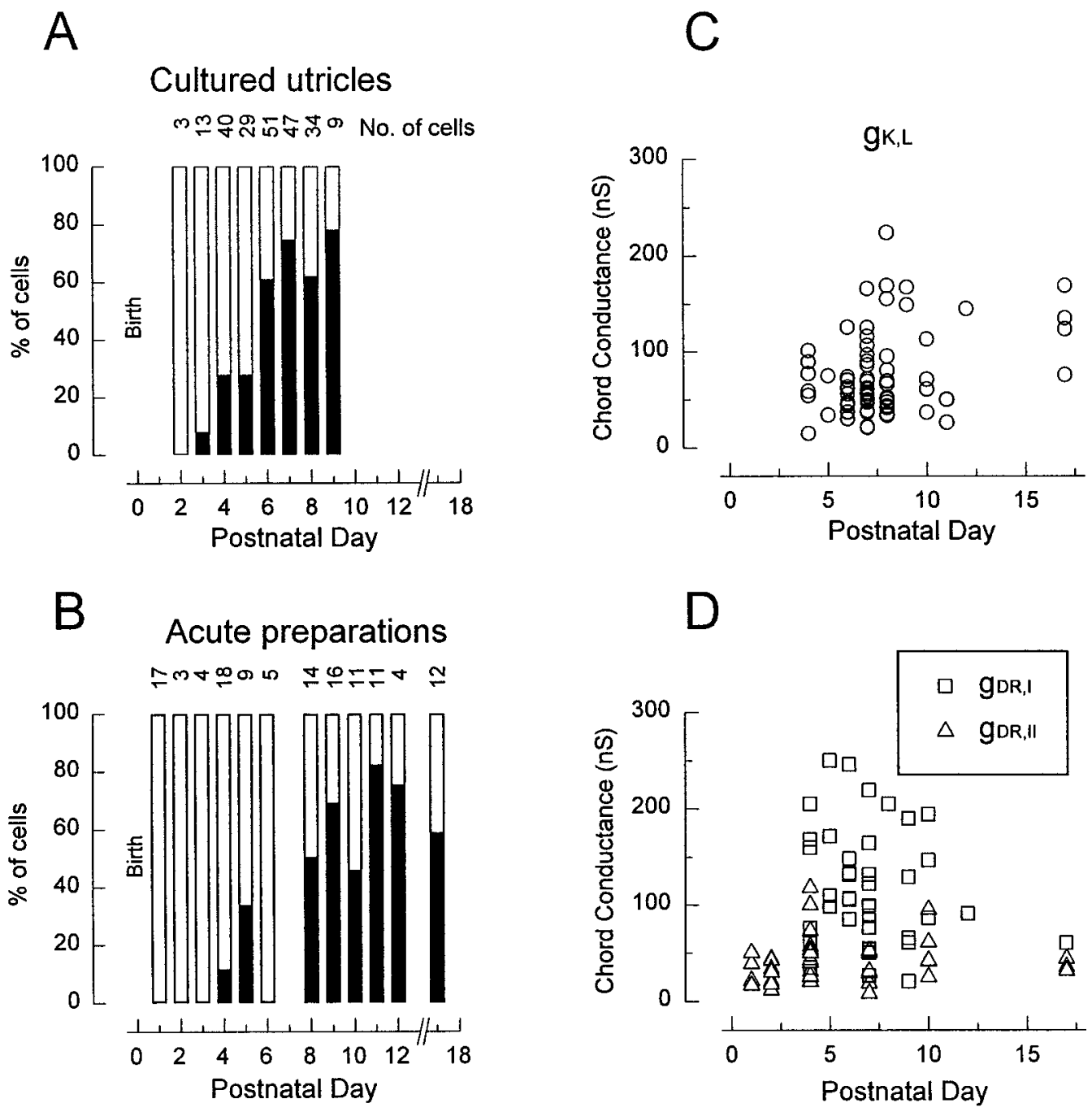

Figure 4. The delayed rectifiers $\mathrm{g}_{\mathrm{K}, \mathrm{L}}$ and $\mathrm{g}_{\mathrm{DR}}$ as functions of age. $A, B$, Changes in incidence with age in cultures $(A)$ and acute preparations $(B)$. In this and subsequent figures, the number of cells from which recordings were obtained at each stage is given at the top of the columns. $C, D$, Maximal sizes of the conductances as functions of age. Zero values are not included. Values calculated as described in Materials and Methods and Results.

is primarily postmitotic by $\mathrm{P} 3$. Whether $\mathrm{g}_{\mathrm{K} 1}$ is retained as these cells mature cannot be determined by inspection of the currents evoked by hyperpolarizing steps in control solutions (Fig. 2A). Activation of $\mathrm{g}_{\mathrm{K} 1}$ would be obscured by deactivation of the much larger $\mathrm{g}_{\mathrm{K}, \mathrm{L}}$, and steady-state $\mathrm{g}_{\mathrm{K} 1}$ is difficult to distinguish from a leak conductance. One test for inward rectifiers is whether extracellular $\mathrm{Cs}^{+}$blocks the steady-state inward current at deeply hyperpolarized potentials at which $g_{K, L}$ is not activated. In four cells with $g_{\mathrm{K}, \mathrm{L}}$ and no detectable slow inward rectifier $\left(\mathrm{g}_{\mathrm{h}}\right)$, extracellular $\mathrm{Cs}^{+}(1$ or $5 \mathrm{~mm})$ reduced the steady-state current at $-124 \mathrm{mV}$ to $28 \pm 16 \%$ of its control value $(-162 \pm 84 \mathrm{pA})$. Thus, a substantial fraction of the small steady-state current is through a $\mathrm{Cs}^{+}$-sensitive conductance rather than a leak conductance. If we assume that the $\mathrm{Cs}^{+}$-sensitive conductance is entirely $\mathrm{g}_{\mathrm{K} 1}$, then we calculate a mean conductance of $2.7 \mathrm{nS}$, which is well within the normal range for cells without $\mathrm{g}_{\mathrm{K}, \mathrm{L}}$ (Fig. $5 B$ ).

$\mathrm{g}_{\mathrm{h}}$ was not present in neonatal cells but was acquired in the same period as $\mathrm{g}_{\mathrm{K}, \mathrm{L}}$. Figure 6 shows the incidence $(A, B)$ and size $(C, D)$ of $\mathrm{g}_{\mathrm{h}}$ as functions of postnatal day for cells with $\mathrm{g}_{\mathrm{K}, \mathrm{L}}(A, C)$ and cells without $\mathrm{g}_{\mathrm{K}, \mathrm{L}}(B, D)$. Data from cultures and from acute preparations are pooled. $\mathrm{g}_{\mathrm{h}}$ was first detected on $\mathrm{P} 3$, and by $\mathrm{P} 4$ its incidence had increased dramatically. In cells without $g_{K, L}$, the incidence continued to increase until $\sim \mathrm{P} 8$. $\mathrm{g}_{\mathrm{h}}$ was present in $88 \%$ of cells without $g_{K, L}$ sampled after P7. In cells with $g_{K, L}$, there was no clear trend with age. $\mathrm{g}_{\mathrm{h}}$ was present in $34 \%$ of all cells with $\mathrm{g}_{\mathrm{K}, \mathrm{L}}$ in the sample.

The size of $\mathrm{g}_{\mathrm{h}}$ varied from 0.11 to $5.7 \mathrm{nS}$ (Fig. 6C,D) but showed no systematic dependence on postnatal day.

Figure 7 summarizes our observations from this and other studies on conductances in neonatal and older hair cells in the mouse utricle. Neonatal cells have a mechanosensitive conductance $\left(\mathrm{g}_{\mathrm{met}}\right)$ (Rüsch and Eatock, 1996b; Holt et al., 1997), a voltage-gated $\mathrm{Ca}^{2+}$ conductance $\left(\mathrm{g}_{\mathrm{Ca}}\right)$ (A. Rüsch and R. A. Eatock, unpublished observations), a voltage-gated $\mathrm{Na}^{+}$conductance $\left(\mathrm{g}_{\mathrm{Na}}\right)$ (Rüsch and Eatock, 1997), a delayed rectifier $\mathrm{K}^{+}$ conductance that activates positive to $-55 \mathrm{mV}\left(\mathrm{g}_{\mathrm{DR}, \mathrm{N}}\right)$, and a fast inward rectifier $\left(\mathrm{g}_{\mathrm{K} 1}\right)$. Mature type I cells differ most obviously from neonatal cells by the expression of a large negatively activating delayed rectifier $\left(\mathrm{g}_{\mathrm{K}, \mathrm{L}}\right)$ and the very large total delayed rectifier conductance $\left(g_{K, L}\right.$ plus $\left.g_{D R, I}\right)$. Mature type II cells differ from neonatal cells in a more subtle way, by the expression of the slow inward rectifier $\mathrm{g}_{\mathrm{h}}$. Approximately one-third of type I cells 


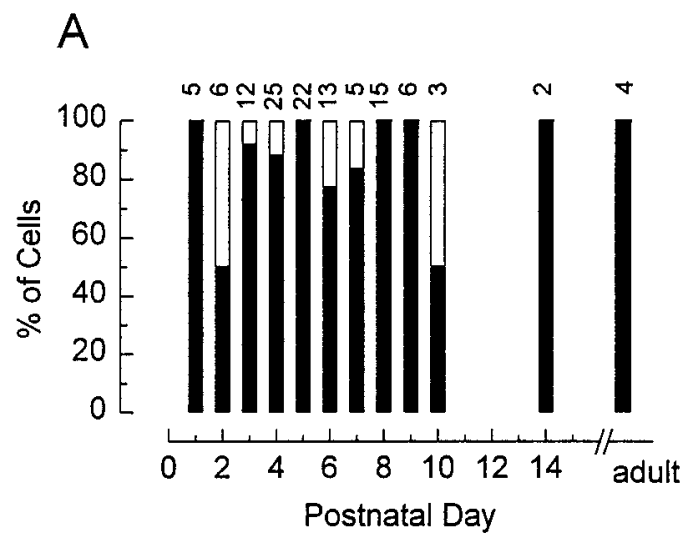

B

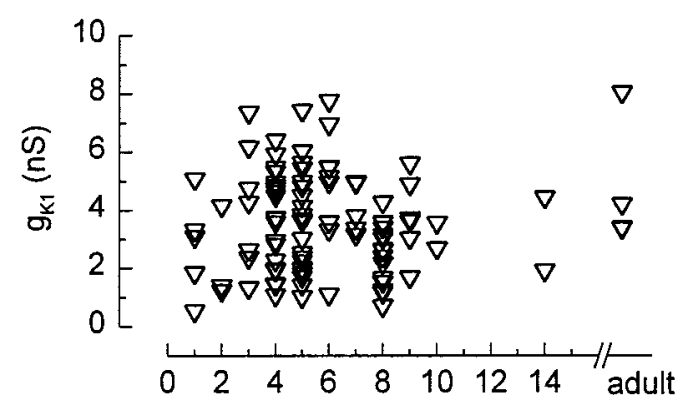

Figure 5. $\mathrm{g}_{\mathrm{K} 1}$ did not vary with postnatal age. Data were pooled from cultures and acute preparations. $A$, Percentage of the cells without $\mathrm{g}_{\mathrm{K}, \mathrm{L}}$ that expressed $\mathrm{g}_{\mathrm{K} 1}$ (filled bars) as a function of age. $B$, Chord conductances measured as described in Materials and Methods and Results. Zero values are not included.

also acquire $\mathrm{g}_{\mathrm{h}}$. It is not clear whether they continue to express $\mathrm{g}_{\mathrm{K} 1} \cdot \mathrm{g}_{\mathrm{Na}}$ was seen in just 1 of 84 type I cells (Rüsch and Eatock, 1997), and we are not sure whether it is retained in adult type II cells.

\section{Morphology}

Does the electrophysiological differentiation of type I and II hair cells coincide with their morphological differentiation? Previous morphological studies of rodent vestibular organs suggested that some maturational changes, e.g., calyx formation and increases in hair bundle height, occur after birth (Dechesne et al., 1986; Anniko, 1990), but these studies have not provided a systematic ultrastructural description of changes during the period of acquisition of voltage-gated conductances just described. We have examined the ultrastructure of utricular epithelia fixed in situ at five time points between P0 and P28 and of cultured utricles on P4, P7, and P10. We classified cells into different types, as described below, and then counted each type at each stage, as described in Materials and Methods.

The sensory epithelia of otolith organs have a distinctive band called the striola. In material fixed in situ, the striola can be distinguished from the extrastriola because the otoconia are relatively small, the hair bundles reverse orientation, and in epithelia from animals older than P4, complex calyces (enveloping $>1$ hair cell) are common (Lindeman, 1973). Recognition of these regions in the cultured organs was more difficult, because the otoconia were removed at the time of culturing, no calyces were present, and hair bundles were often disturbed by mechanical removal of the otolithic membrane so that it was difficult to ascertain their orientation. Therefore, we did not attempt to subdivide the cultures into striolar and extrastriolar zones.

\section{Cell type classification}

The electron micrographs in Figures 8 and 9 illustrate the features that we used to classify cells.

Supporting cells were relatively narrow cells with dark (electron-dense) cytoplasm and located between the lighter hair cells. Supporting cells had many small- to medium-sized secretory granules ( $\sim 15-20$ in a single section) (Figs. 8A,B, 9C), short apical microvilli, and an apical reticular meshwork (Fig. 9B, $R M$ ) (Wersäll, 1956) instead of a cuticular plate. Their nuclei were located in a layer at the base of the epithelium (Fig. $8 C, S C$ ).

Hair cells were distinguished from supporting cells by the more apical location of the nucleus and by lighter cytoplasm and nucleoplasm. Hair cells were further classified as immature, type I, type II, or undefined.

Immature hair cells appeared to be intermediate between supporting cells and mature hair cells. Li and Forge (1997) observed comparable cells in guinea pig utricular epithelium after aminoglycoside-induced damage and interpreted them as showing transdifferentiation of supporting cells to hair cells. The immature cells in our specimens typically had one to five large secretory granules per section (Figs. $8 A, 9 A, C, S G$ ), in contrast to none in mature hair cells and more numerous smaller granules in supporting cells. The apical microvilli of immature hair cells had lengths and diameters that were intermediate between those of supporting cell microvilli and those of true stereocilia (Fig. 8A, $C$, $M V)$. There was no apical reticular meshwork and frequently either no cuticular plate or one that was poorly defined (Fig. 8A). The electron density of the cytoplasm ranged from dark, as in supporting cells (Fig. 8A, left), through intermediate (Fig. 8A, right) to light, as in more mature hair cells (Fig. $8 C$, right). The immature hair cells with the darkest cytoplasm had more basal nuclei and often retained their attachments to the basement membrane, as observed in regenerating epithelia by Li and Forge (1997).

The primary attribute used to classify hair cells as type I or type II has been the form of the afferent synaptic contact. Because synaptogenesis is incomplete in neonatal utricles and the cultures were denervated, we also used a set of secondary attributes to distinguish type I from type II hair cells. These attributes have been noted in the course of ultrastructural examination of mature vestibular organs from chinchillas (Lysakowski, 1996; Lysakowski and Goldberg, 1997).

Hair cells were classified as type I if they received a full or partial calyx ending. A full calyx is an afferent nerve terminal that surrounds the basolateral membrane of the hair cell nearly up to the tight junctions that segregate apical and basolateral cell surfaces (Fig. 9B,C). We defined an afferent terminal to be a partial calyx rather than a large bouton terminal if the appositional length of its contact with the hair cell exceeded $5 \mu \mathrm{m}$ and/or if the parent branch extended in both directions around the base of the hair cell (Figs. $8 A, 9 A, P C$ ). Hair cells were also considered to be type I if they lacked calyces but fulfilled two or more of the following secondary criteria: a constricted region (neck) below the cuticular plate (Fig. 9B-D) (Wersäll, 1956; Correia et al., 1989); electron-dense patches of clumped heterochromatin in the nucleus (Figs. 8B, $C, 9 B$ ) (Lysakowski, 1996); an apical surface that bulges into the endolymphatic lumen (Fig. 9D) (Favre, 1986; Lysakowski, 1996); and, relative to neighboring type II cells, 

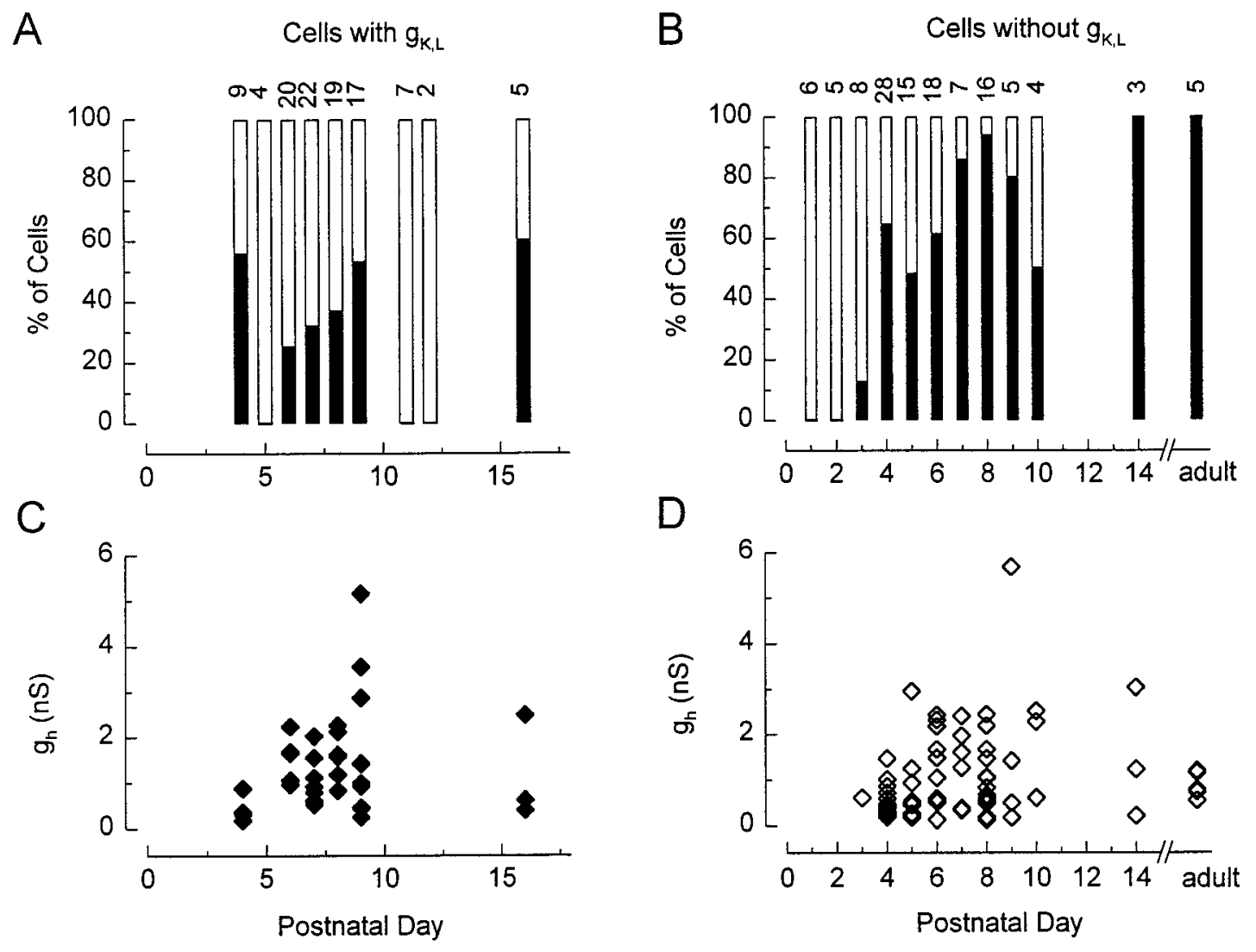

Figure 6. $\mathrm{g}_{\mathrm{h}}$ as a function of postnatal age. Data from cultures and acute preparations were pooled. $A, B$, Percentages of cells that expressed $\mathrm{g}_{\mathrm{h}}$ and $\mathrm{g}_{\mathrm{K}, \mathrm{L}}$ $(A)$ or $\mathrm{g}_{\mathrm{h}}$ and no $\mathrm{g}_{\mathrm{K}, \mathrm{L}}(B)$. $C, D$, Chord conductances in cells with $\mathrm{g}_{\mathrm{K}, \mathrm{L}}(C)$ and without $\mathrm{g}_{\mathrm{K}, \mathrm{L}}(D)$. See Materials and Methods and Results for details. Zero values are not included.

thicker stereocilia (Fig. 8A-C, $S$ ) (Lysakowski, 1996) and largerdiameter mitochondria (Figs. $8 A-C, 9 B, M$ ) (Lysakowski, 1992).

Type II hair cells included hair cells that were not immature, that had no calyx, and that fulfilled two or more of the following secondary criteria: they did not have necks and, relative to neighboring type I cells, their stereocilia were thinner (Fig. 8A-C, $S$ ); mitochondria had smaller diameters (Figs. $8 A-C, 9 B, M$ ); and nuclear heterochromatin was more uniform (Figs. $8 B, C, 9 B$ ).

Test of the secondary attributes in mature tissue. In many cells, not all of the secondary attributes followed the patterns described. When secondary attributes were ambiguous or in conflict, we called the cells undefined hair cells. This category also included hair cells for which only part of the cell was in the sample (Fig. $8 A$, far right $U$ ). Despite these exceptions and the qualitative nature of the secondary attributes, a test of the method in mature tissue suggests that they are good predictors of cell type. We classified the hair cells of one P28 sample twice, once according to the presence or absence of calyces and a second time using the secondary attributes but ignoring the presence of any calyx ending on the hair cells. Using the primary attribute alone (calyx or no calyx), 60 of 94 hair cells were classified as type I, 27 as type II, and 7 were undefined, i.e., we could not determine whether a calyx was present because only a small part of the cell was present. Using secondary attributes alone, we classified 42 as type I, 16 as type II, and 36 as undefined. Thus, secondary attributes are not always able to identify cell type as defined by the afferent ending. Consistent with this, the fraction of undefined hair cells was higher in the denervated cultures than in material fixed in situ
(Fig. $10 B-D$ ). On the other hand, just 3 of 94 cells were classified as type II by one method and type I by the other method.

In summary, the secondary attributes provide a way to classify cell type when afferents are missing. Use of the secondary attributes alone results in more undefined cells but is reasonably accurate with respect to the cells that are classified as type I or type II.

\section{Changes with postnatal age}

In Figure $10 A$, cells from epithelia fixed in situ are divided into supporting cells and hair cells and are shown as percentages of the total number of cells at the five sampled postnatal days. The percentage of hair cells increased from $\sim 40 \%$ on $\mathrm{P} 0$ to $\sim 60 \%$ by P28. This is not likely to reflect birth of new cells, because Ruben (1967) showed that terminal mitosis of all but a small percentage $(<3 \%)$ of mouse utricular hair cells precedes birth. Consistent with this, we observed a few mitotic figures at $\mathrm{P} 0$ and none later. It appears that between P0 and P28, some supporting cells transformed into hair cells. This is supported by the transitional appearance of the immature hair cells.

Figure $10, B-D$, shows changes with postnatal day in the percentages of each hair cell type in the cultures $(B)$ and in the striolar $(C)$ and extrastriolar $(D)$ regions of utricles fixed in situ (supporting cells are not included). The following trends can be discerned.

Cell type. In cultures and in vivo, the percentages of type I and type II cells increased with postnatal age at the expense of the immature and undefined categories. In situ, $50 \%$ of cells were 


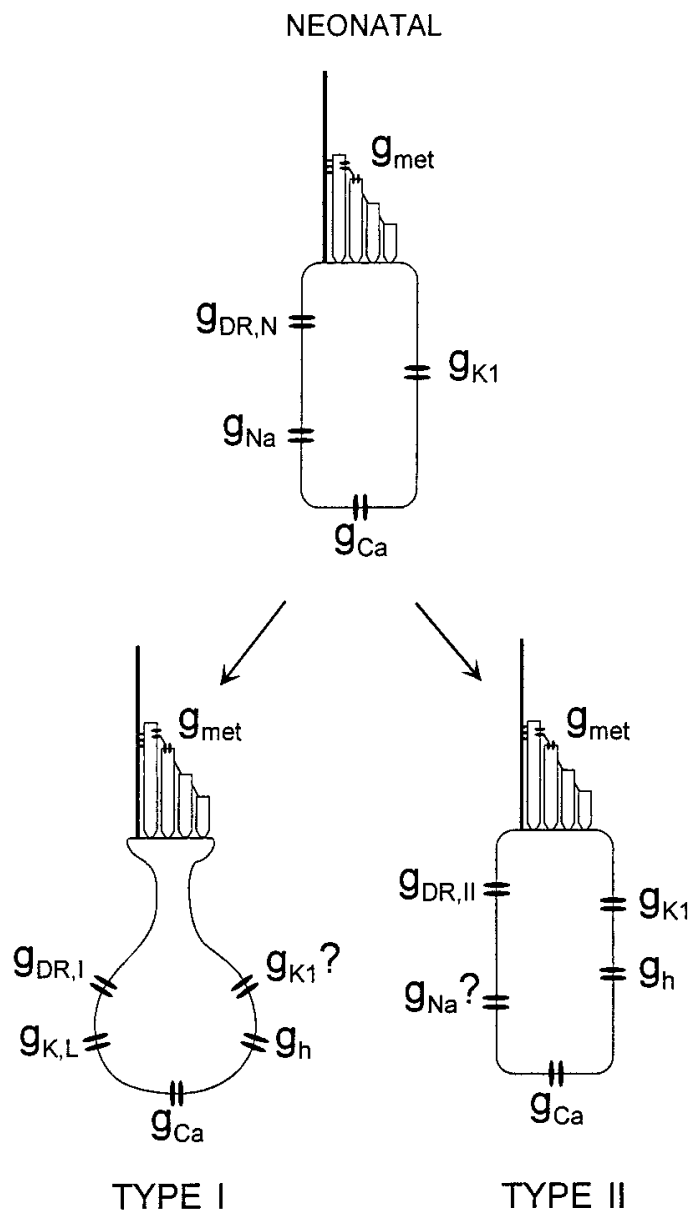

Figure 7. Schematic overview of the conductances in neonatal and differentiated type I and type II hair cells of the mouse utricle.

classified as type I or type II on P0 (Fig. 10C,D, data from both regions pooled). This increased by P10 to $\sim 90 \%$ in situ and $\sim 70 \%$ in culture (Fig. 10B). The cultures had more undefined hair cells, presumably because only secondary attributes are available. In the epithelia fixed in situ, the percentage of undefined cells was similar at P10 and P28 (9\% pooled across both regions), suggesting that this represents the small parts of cells at the edges of the samples rather than immaturity. At P28, the percentage of type I hair cells was $65 \%$ in the extrastriolar region, $54 \%$ in the striolar region, and $63 \%$ when data from both regions were pooled. These percentages are in close agreement with the percentages of cells with $g_{\mathrm{K}, \mathrm{L}}$ at P6 and later and not very different from the percentage of type I hair cells in the mature guinea pig utricle and chinchilla crista (51\% in both) (Lindeman, 1969; Fernández et al., 1995).

Although similar final percentages of type I cells were obtained by morphological and electrophysiological criteria, the morphological changes were more gradual than the electrophysiological changes. At P0, there were cells that were morphologically type I that did not express $\mathrm{g}_{\mathrm{K}, \mathrm{L}}$, and after P6 some cells that were not fully differentiated in appearance expressed the mature complement of voltage-gated channels.

Striola versus extrastriola. Differentiation in the striola appeared to lead differentiation in the extrastriola; in the striola the proportions of type I cells changed very little postnatally. Other studies have shown that the frequency of terminal mitoses peaks earlier in the striola (E14) than in the extrastriola (E15) (Sans and Chat, 1982) and that the central zone of the utricular epithelium, which includes the striola, leads peripheral zones in both the development of hair bundles (Mbiene et al., 1984) and synaptogenesis (Sans and Dechesne, 1987).

Calyx formation. On P0, only one full calyx was seen, but $29 \%$ of striolar hair cells and $21 \%$ of extrastriolar hair cells were contacted by partial calyces. In a sample not included in the counts in Figure 10, partial calyces contacted two immature hair cells, consistent with cells committing to a type I identity at an early stage. Full calyces were first found in appreciable numbers at $\mathrm{P} 4$, when they were exclusively simple. They were present on a higher percentage of hair cells in the striola than in the extrastriola.

Cell shape. Cell shape was not a reliable marker at early stages. Partial calyces contact cells with no necks in Figures $8 A(\mathrm{P} 0)$ and $9 A$ (P4). The distinctive flask shape (Fig. 9B-D) of mature type I cells was more frequently seen beginning at P7. The flask shape did not depend on the calyx (Fig. 9D).

\section{DISCUSSION}

Between P4 and P7, type I cells differentiated from neonatal cells by greatly increasing the density of delayed rectifier $\mathrm{K}^{+}$channels of at least two types and in some cases acquiring $\mathrm{g}_{\mathrm{h}}$. Type II cells differentiated by acquiring $\mathrm{g}_{\mathrm{h}}$. No specific morphological events correlated in time with the electrophysiological changes. Morphological differentiation was more gradual, with some cells recognizable as type I or II by $\mathrm{P} 0$, and some continuing differentiation past P7 (Fig. 10). Results with denervated cultures showed that neither calyx formation nor sustained postnatal innervation of any kind was required for electrophysiological and morphological differentiation of type I and type II hair cells. Thus, despite the concurrence of calyx formation and $\mathrm{g}_{\mathrm{K}, \mathrm{L}}$ acquisition in vivo, these distinguishing marks of the mature type I cell are independently acquired. The existence of cells with ultrastructural traits that are intermediate between supporting cells and hair cells suggests that during normal development cells postmitotically transform from supporting cells to hair cells. Postnatal changes in the proportions of the two cell types support this interpretation.

\section{Electrophysiological differentiation of hair cells}

Conductances similar to those found in neonatal mouse utricular hair cells occur early in development in hair cells from other organs. In vestibular hair cells in cultured chick otocysts (Sokolowski et al., 1993), delayed rectifier, fast inward rectifier, and voltage-gated $\mathrm{Na}^{+}$and $\mathrm{Ca}^{2+}$ conductances have all been identified at relatively early stages. Neonatal mouse cochlear hair cells transduce (Kros et al., 1992) and express a slow delayed rectifier and $\mathrm{g}_{\mathrm{Na}}$ and $\mathrm{g}_{\mathrm{Ca}}$ (Kros et al., 1993, 1998). With time, developing hair cells acquire new outwardly rectifying conductances: $g_{K, L}$ in mouse utricular type I hair cells; $g_{A}$ and $g_{K(C a)}$ in chick otocyst cells (Sokolowski et al., 1993); $\mathrm{g}_{\mathrm{K}(\mathrm{Ca})}$ in chick cochlear hair cells (Fuchs and Sokolowski, 1990); and a fast conductance, possibly $\mathrm{g}_{\mathrm{K}(\mathrm{Ca})}$, in mouse cochlear cells (Kros et al., 1998).

$\mathrm{g}_{\mathrm{K}, \mathrm{L}}$ is unusual among delayed rectifiers in its $\mathrm{Cs}^{+}$permeability and very negative activation range. High $\mathrm{Cs}^{+}$permeability has been observed in other delayed rectifiers (Hadley and Hume, 1990), however, and the activation range of some delayed rectifiers can be shifted by such simple manipulations as increasing intracellular ATP (Perozo and Bezanilla, 1990). Therefore, $g_{K, L}$, like other delayed rectifiers, is probably encoded by $\mathrm{Kv}$ genes. Postnatal onset of Kv subunit expression has been shown in the 

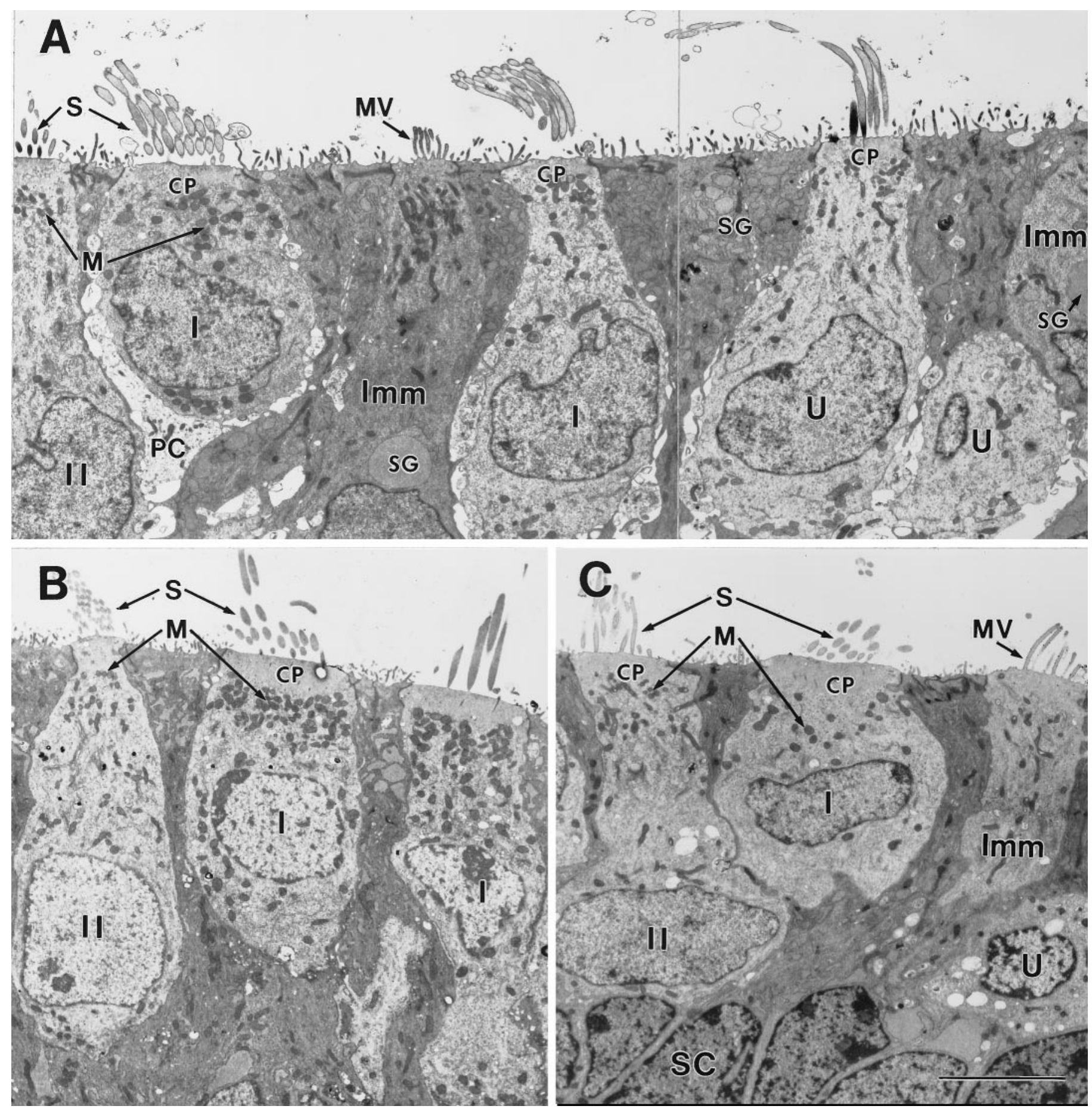

Figure 8. Ultrastructure of the neonatal and early postnatal mouse utricle. $A, \mathrm{P} 0 ; B, \mathrm{P} 3 ; C, \mathrm{P} 4$. The epithelia shown in $A$ and $B$ were fixed in situ. The epithelium shown in $C$ was excised and cultured on P1 and fixed $3 \mathrm{~d}$ later. $A$, Adjacent to the striolar region (in the juxtastriolar region) (Fernández et al., 1990). $B, C$, Striolar region. $A$, Immature (Imm) hair cells had some features of supporting cells $(S C$, see $C)$, including microvilli $(M V)$ instead of stereocilia, and secretory granules $(S G)$. They were distinguished from supporting cells by their longer microvilli and more apical nuclei, and because they had a few large secretory granules rather than many small ones. Unlike more mature hair cells, they lacked cuticular plates and had fine elongate microvilli instead of stereocilia. Even at P0, it is possible to classify some hair cells as type I or type II. The cell labeled $I$ in its nucleus (left) has an immature partial calyx $(P C)$. The left cell $(I I)$ has finer stereocilia $(S)$ and smaller mitochondria $(M)$, both traits of mature type II hair cells. The hair cell in the middle has relatively thick stereocilia and large mitochondria, consistent with it being type I. Large afferent endings on it may be an early stage of calyx formation. The hair cell to its right is undefined $(U)$, because it has relatively thick stereocilia (a type I trait) but small mitochondria (a type II trait). $C P$, Cuticular plate. $B, C$, Hair cells grown in culture $(C)$ acquired differentiated traits similar to those seen $i n$ situ $(B)$. Note the thicker stereocilia $(S)$ and larger mitochondria $(M)$ in the type I hair cells relative to the adjacent type II cells. The type I nuclei had more clumps of dark heterochromatin than did the type II nuclei. Type I nuclei are often more apical than type II nuclei at this stage but not later, after the neck forms (Fig. $9 B, D$ ). $S C$, Supporting cell labeled in its nucleus. Scale bar, $5 \mu \mathrm{m}$. 

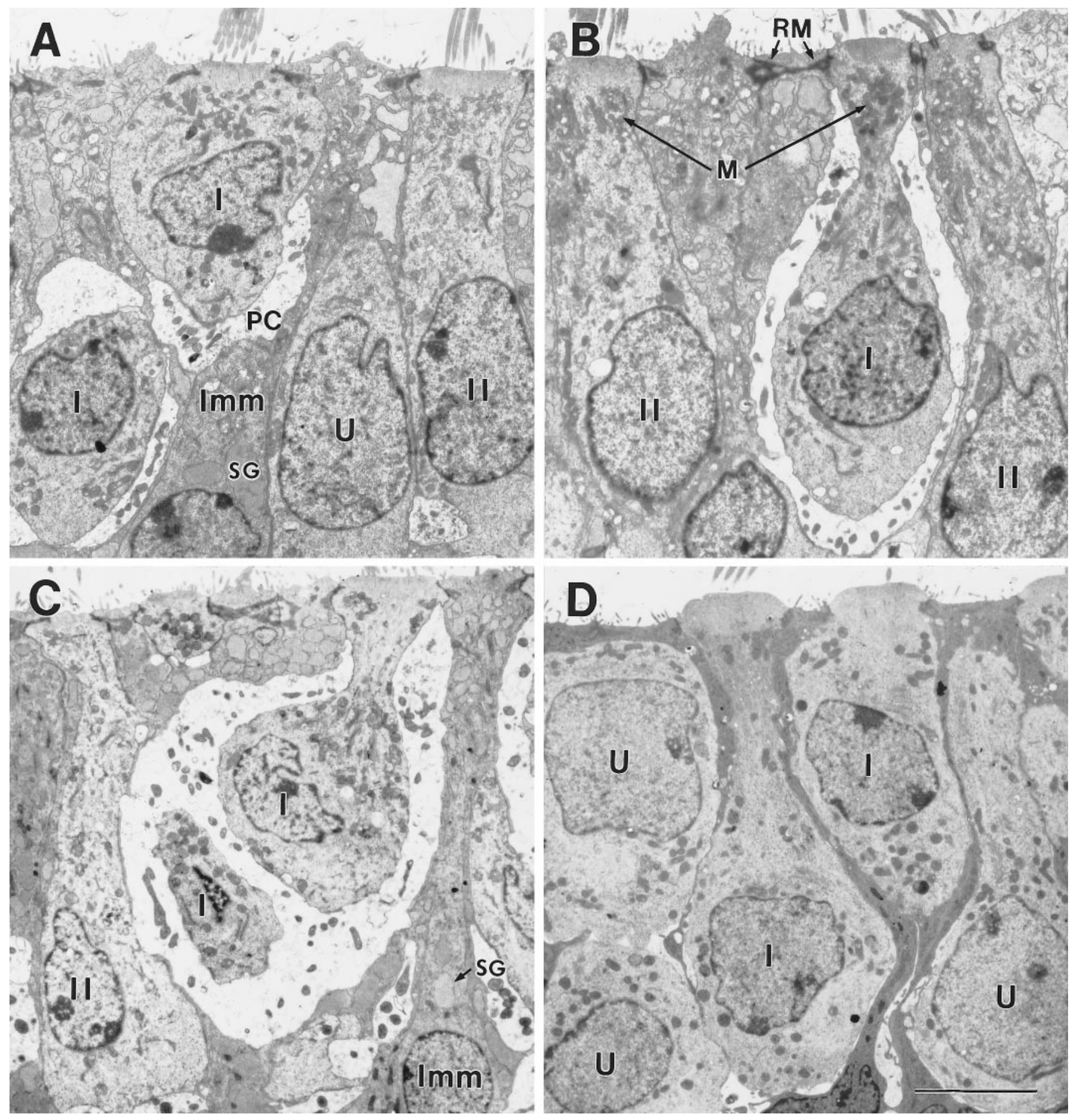

Figure 9. Type I morphologies in the early postnatal mouse utricle. $A, B$, $\mathrm{P} 4$, extrastriolar region fixed in situ. $C$, $\mathrm{P} 7$, striolar region fixed in situ. $D$, Juxtastriolar region cultured on P1 and fixed 6 d later (P7). On P3-P4, some type I hair cells lacked calyces (Fig. $8 C$ ), and others had partial calyces $(A$, $P C)$ or full calyces $(B, I)$. Some type I cells $(B)$ had the necks that are characteristic of mature type I cells, and others did not $(A)$. The neck is not a response to the calyx, because it was sometimes seen in cultures $(D)$. As the type I cells developed necks, their nuclei tended to move toward the base of the epithelium; compare the adjacent type I cells in $D$. Complex calyces, which surround more than one type I cell $(C)$ and are common in the mature striola, were first seen on P7. The bulging apical surfaces of the type I cells in $D$ are a secondary trait. In $B$, the apical reticular meshwork (RM) of a supporting cell is labeled. Other labels are as in Figure 8. Scale bar, $5 \mu \mathrm{m}$.

rat brain (Perney et al., 1992; Du et al., 1996). Although we have focused on the incidence of each conductance, our data provide some information about changes in the level of ion channel expression in single cells. If it increases with a time course of days, $\mathrm{g}_{\mathrm{K}, \mathrm{L}}$ and $\mathrm{g}_{\mathrm{h}}$ should be relatively small on the first days that they are detected (P2-P4). Although there was wide scatter in $\mathrm{g}_{\max }$ values, no trend with age was observed (Figs. $4 C, 6 C, D$ ), which is consistent with each cell expressing its full complement of channels within $1 \mathrm{~d}$.

The postnatal electrophysiological differentiation of type I hair 
A

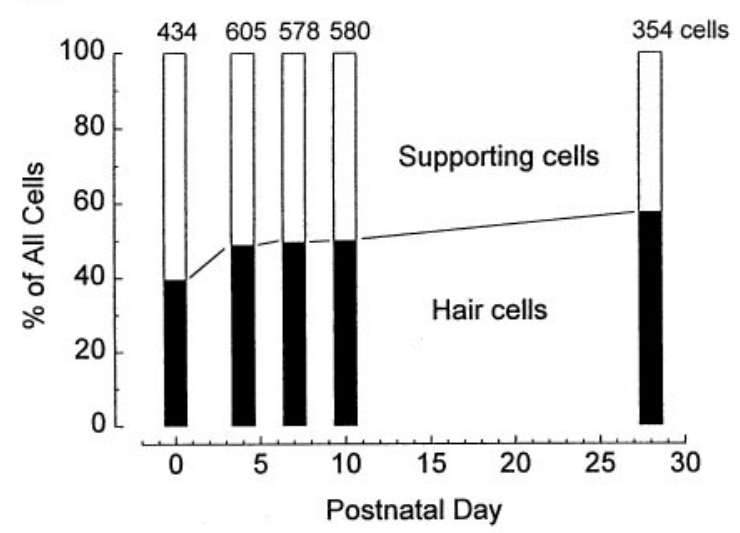

B

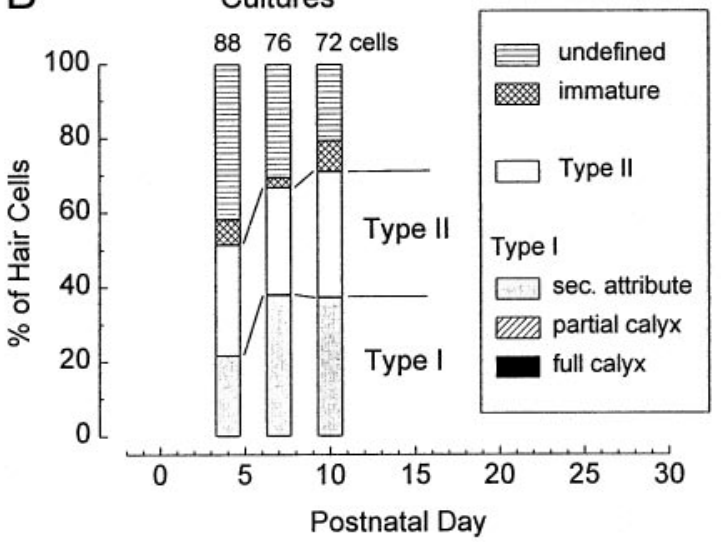

C

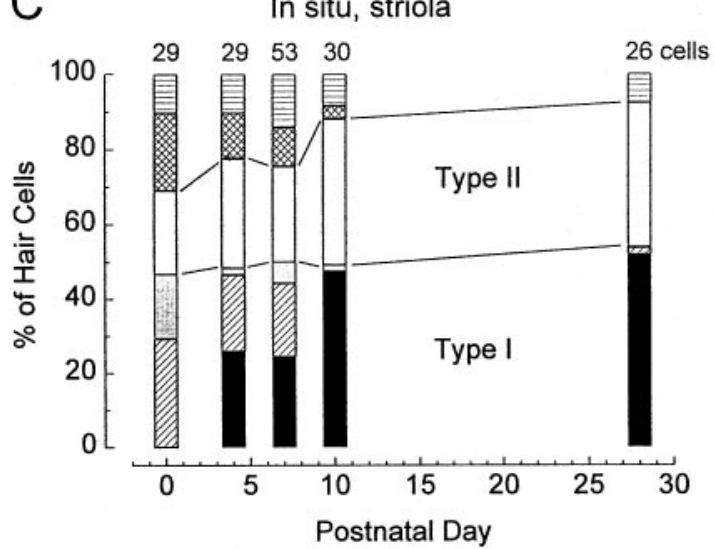

D

In situ, extrastriola

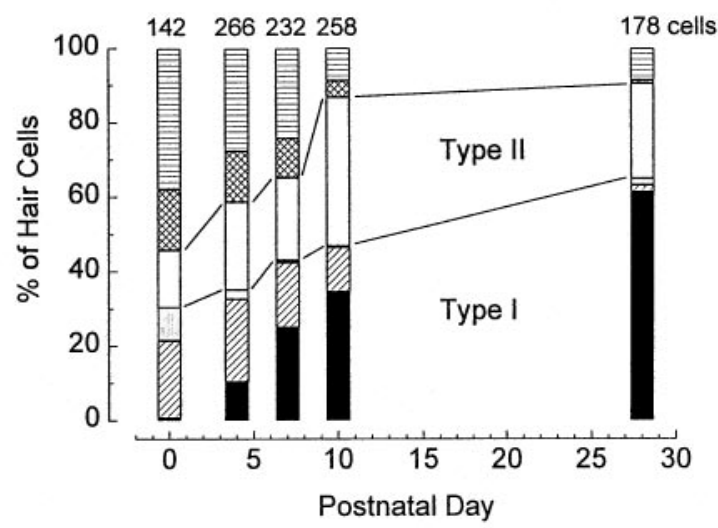

Figure 10. Percentages of cell types as functions of postnatal age. The numbers of cells for all samples at each stage are shown at the top of the columns. $A$, Percentages of hair cells and supporting cells. All data are from epithelia fixed in situ: two samples at P28 and three samples at each of the other stages. Percentages were separately calculated for each sample at each age and then averaged together. $B-D$, Percentages of hair cell types as functions of postnatal age. The key in $B$ applies to all three histograms. Type I cells were identified by the presence of a full calyx or partial calyx or, in the absence of any calyceal contact, by the secondary attributes described in Results. The lines joining adjacent columns separate the type I, type II, and other (immature plus undefined) categories. The percentage of cells that could be classified as type I or type II increased with age. $B$, Utricles that were cultured on $\mathrm{P} 1$ and fixed 3, 6, or 9 d later. Counts were made from one sample at each stage. $C, D$, Counts in the striolar $(C)$ and extrastriolar $(D)$ regions of utricles that were fixed in situ. Counts were made from three samples each at P0, P4, P7, and P10 and two samples at P28. Pooled in situ data from the striolar and extrastriolar regions (data not shown) resemble the data from the extrastriolar region, which is $\sim 90 \%$ of the total area.

cells is distinguished by an extraordinary increase in the size of the total delayed rectifier $\mathrm{K}^{+}$conductance $\left(\mathrm{g}_{\mathrm{K}, \mathrm{L}}\right.$ plus $\left.\mathrm{g}_{\mathrm{DR}, \mathrm{I}}\right)$ relative to neonatal cells and to mature type II hair cells in the same epithelium and in other organs. The associated reduction in input resistance profoundly attenuates the voltage changes evoked by intracellular current injections and increases their bandwidth (Rennie et al., 1996; Rüsch and Eatock, 1996b). That a hair cell would express a conductance that acts to severely reduce receptor potentials may seem surprising, but one potentially positive outcome would be to minimize the nonlinearities that in other hair cells are excited by large receptor potentials as the activation levels of voltage-gated conductances change.

\section{Defining type I hair cells}

Since type I cells were first described by Wersäll (1956), they have been defined by the calyx ending. However, they have other distinguishing features. In previous electrophysiological experiments on isolated hair cells, cells were classified as type I if they had an amphora shape. The strong correlation between the amphora shape and $\mathrm{g}_{\mathrm{K}, \mathrm{L}}$ in diverse (mature) organs (Ricci et al., 1996) encouraged us to use $g_{K, L}$ as a type $I$ marker in our preparations in which the shape of the cell was often not visible or had not yet differentiated (Figs. 8, 9). We also introduced an ultrastructural classification scheme by which hair cells were classified as type I if they were contacted by a calyx or exhibited two or more other features typical of type I cells in mature organs. Both the electrophysiological and ultrastructural methods will be useful in situations in which innervation is not complete or has been disrupted, e.g., by aminoglycoside antibiotics (Forge et al., 1993; Weisleder and Rubel, 1993) or by knock-out of genes involved in development (Ernfors et al., 1995). The secondary ultrastructural attributes described here were first noted in chinchilla semicircular canal organs (Lysakowski, 1996; Lysakowski and Goldberg, 1997), suggesting that they may apply generally to rodent vestibular organs.

We show that in immature epithelia, type I cells that lack a calyx may be distinguished from type II cells on other grounds, either morphological or electrophysiological. Thus, the observation that calyces are slow to regenerate after damage to the vestibular epithelium (Weisleder and Rubel, 1993) does not necessarily mean that type I hair cells are slow to regenerate. In 
developing and regenerating vestibular epithelia, the decision as to whether a hair cell is type I or type II requires more information than the cell shape and the form of innervation, which is typically all that is available in light microscopic analyses.

\section{Ontogeny of hair cells}

In mouse vestibular organs, the frequency of terminal mitoses of hair cells and supporting cells peaks between E14 and E18, decreasing to almost none by P3 (Ruben, 1967). Penetration of the otocyst by the eighth nerve begins on E12 (Van de Water, 1984), 2 d before the sensory epithelia of individual organs can be recognized (Sher, 1971). By E16, immature hair cells with short stereocilia are evident (Nordemar, 1983a). Synaptic contacts between afferent nerve fibers and hair cells are first seen on E15 (Mbiene et al., 1988) but are rare before E18 (Van de Water et al., 1977). Our morphological data support previous reports that full calyx endings are first present in significant numbers several days after birth (Nordemar, 1983b; Anniko, 1990) but that partial calyces are seen as early as E18 (Van de Water et al., 1977).

In the mouse inner ear, innervation is thought to have little effect on the differentiation of the sensory epithelium at least up to P0, as evaluated at the light microscopic level (Van de Water, 1984; Raymond, 1987; Corwin and Cotanche, 1989; Ernfors et al., 1995). Our results with cultures show that removal of the nerve supply at birth has little effect on several important attributes of the differentiation of hair cells into type I and type II.

Supporting cells and hair cells come from a common progenitor pool (for review, see Fekete, 1996). The increase in the hair cell to supporting cell ratio and the decline in the immature hair cell type in the first postnatal month (Fig. 10) together suggest that some hair cells arise from the postnatal transformation of supporting cells. Such transformations are a source for regenerating hair cells in damaged epithelia (Baird et al., 1996; Jones and Corwin, 1996; Li and Forge, 1997). The gradual decrease in immature hair cell type suggests that some hair cells are not fully mature morphologically until weeks after terminal mitosis, reflecting either a slow overall time course or a delay in the onset of differentiation. Many hair cells must mature faster; $\sim 45 \%$ of hair cells belong to morphologically differentiated hair cell classes by P0 (Fig. 10C,D), 8 d after terminal mitoses begin (Ruben, 1967).

During regeneration of vestibular epithelia after aminoglycoside treatments, calyx endings form later than bouton endings (Rubel et al., 1991), contributing to an impression that the type I hair cell is a "super-differentiated" type II hair cell. Alternatively, the two cell types may commit to different developmental paths long before either type is mature, possibly as early as terminal mitosis (Sans and Chat, 1982). Our electrophysiological data argue against serial development from mature type II cells to mature type I cells and for parallel emergence of the two cell types from the neonatal pool (Fig. 7). It is also possible that the electrophysiological differentiation of the two cell types precedes the first postnatal week. A closer look at the basolateral conductances in neonatal hair cells may reveal subtle heterogeneity, for example, in the delayed rectifier channels that activate positive to $-55 \mathrm{mV}$.

\section{REFERENCES}

Anniko M (1990) Development of the vestibular system. In: Development of sensory systems in mammals (Coleman JR, ed), pp 341-400. New York: Wiley.

Baird RA, Steyger PS, Schuff NR (1996) Mitotic and nonmitotic hair cell regeneration in the bullfrog vestibular otolith organs. Ann NY Acad Sci 781:59-70.
Correia MJ, Lang DG (1990) An electrophysiological comparison of solitary type I and type II vestibular hair cells. Neurosci Lett 116:106-111.

Correia MJ, Christensen BN, Moore LE, Lang DG (1989) Studies of solitary semicircular canal hair cells in the adult pigeon. I. Frequencyand time-domain analysis of active and passive membrane properties. J Neurophysiol 62:924-945.

Corwin JT, Cotanche DA (1989) Development of location-specific hair cell stereocilia in denervated embryonic ears. J Comp Neurol 288:529-537.

Dechesne CJ, Mbiene J-P, Sans A (1986) Postnatal development of vestibular receptor surfaces in the rat. Acta Otolaryngol (Stockh) 101:11-18.

DeGroot JCMJ, Veldman JE, Huizing EH (1987) An improved fixation method for guinea pig cochlear tissues. Acta Otolaryngol (Stockh) 104:234-242.

Du J, Zhang L, Weiser M, Rudy B, McBain CJ (1996) Developmental expression and functional characterization of the potassium-channel subunit Kv3.1b in parvalbumin-containing interneurons of the rat hippocampus. J Neurosci 16:506-518.

Eatock RA, Chen WY, Saeki M (1994) Potassium currents in mammalian vestibular hair cells. Sens Syst 8:21-28.

Ernfors P, Van de Water TR, Loring J, Jaenisch R (1995) Complementary roles of BDNF and NT-3 in vestibular and auditory development. Neuron 14:1153-1164.

Favre D (1986) Freeze-fracture study of the vestibular hair cell surface during development. Anat Embryol 175:69-76.

Fekete DM (1996) Cell fate specification in the inner ear. Curr Opin Neurobiol 6:533-541.

Fernández C, Baird RA, Goldberg JM (1988) The vestibular nerve of the chinchilla. I. Peripheral innervation patterns in the horizontal and superior semicircular canals. J Neurophysiol 60:167-181.

Fernández C, Goldberg JM, Baird RA (1990) The vestibular nerve of the chinchilla. III. Peripheral innervation patterns in the utricular macula. J Neurophysiol 63:767-780.

Fernández C, Lysakowski A, Goldberg JM (1995) Hair-cell counts and afferent innervation patterns in the cristae ampullares of the squirrel monkey with a comparison to the chinchilla. J Neurophysiol 73:1253-1281.

Forge A, Li L, Corwin JT, Nevill G (1993) Ultrastructural evidence for hair cell regeneration in the mammalian inner ear. Science 259:1616-1619.

Fuchs PA, Evans MG (1990) Potassium currents in hair cells isolated from the cochlea of the chick. J Physiol (Lond) 429:529-551.

Fuchs PA, Sokolowski BHA (1990) The acquisition during development of Ca-activated potassium currents by cochlear hair cells of the chick. Proc R Soc Lond B Biol Sci 241:122-126.

Goldberg JM, Desmadryl G, Baird RA, Fernández C (1990) The vestibular nerve of the chinchilla. V. Relation between afferent discharge properties and peripheral innervation patterns in the utricular macula. J Neurophysiol 63:791-804.

Goodman MB, Art JJ (1996) Positive feedback by a potassium-selective inward rectifier enhances tuning in vertebrate hair cells. Biophys $\mathbf{J}$ 71:430-442.

Gundersen HJ (1986) Stereology of arbitrary particles. A review of unbiased number and size estimators and the presentation of some new ones, in memory of William R. Thompson. J Microsc 143:3-45.

Hadley RW, Hume JR (1990) Permeability of time-dependent $\mathrm{K}^{+}$channel in guinea pig ventricular myocytes to $\mathrm{Cs}^{+}, \mathrm{Na}^{+}, \mathrm{NH}_{4}{ }^{+}$and $\mathrm{Rb}^{+}$. Am J Physiol 259:1448-1454.

Hagiwara S, Miyazaki S, Rosenthal NP (1976) Potassium current and the effect of cesium on this current during anomalous rectification of the egg cell membrane of a starfish. J Gen Physiol 67:621-638.

Holt JR, Eatock RA (1995) The inwardly rectifying currents of saccular hair cells from the leopard frog. J Neurophysiol 73:1484-1502.

Holt JR, Corey DP, Eatock RA (1997) Mechanoelectrical transduction and adaptation in hair cells of the mouse utricle, a low-frequency vestibular organ. J Neurosci 17:8739-8748.

Jones JE, Corwin JT (1996) Regeneration of hair cells after laser ablation in the lateral line system: hair cell lineage and macrophage behavior revealed by time-lapse video microscopy. J Neurosci 16:649-662.

Klee R, Ficker E, Heinemann U (1995) Comparison of voltagedependent potassium currents in rat pyramidal neurons isolated from hippocampal regions CA1 and CA3. J Neurophysiol 74:1982-1995. 
Kros CJ, Crawford AC (1990) Potassium currents in inner hair cells isolated from the guinea-pig cochlea. J Physiol (Lond) 421:263-291.

Kros CJ, Rüsch A, Richardson GP (1992) Mechano-electrical transducer currents in hair cells of the cultured neonatal mouse cochlea. Proc R Soc Lond B Biol Sci 249:185-193.

Kros CJ, Rüsch A, Richardson GP, Russell IJ (1993) Sodium and calcium currents in cultured cochlear hair cells of neonatal mice. J Physiol (Lond) [Abstr] 473:231P.

Kros CJ, Ruppersberg JP, Rüsch A (1998) Expression of a potassium current in inner hair cells during development of hearing in mice. Nature 394:281-283.

Lapeyre PNM, Guilhaume A, Cazals Y (1992) Differences in hair bundles associated with type I and type II vestibular hair cells of the guinea pig saccule. Acta Otolaryngol (Stockh) 112:635-642.

Li L, Forge A (1997) Morphological evidence for supporting cell to hair cell conversion in the mammalian utricular macula. Int J Dev Neurosci 15:433-446.

Lindeman HH (1969) Studies on the morphology of the sensory regions of the vestibular apparatus. Ergeb Anat Entwicklungsgesch 42:1-113.

Lindeman HH (1973) Anatomy of the otolith organs. Adv Oto-RhinoLaryngol 20:405-433.

Lysakowski A (1992) Possible morphological features to distinguish calyx vs. dimorphic type I vestibular hair cells in the chinchilla cristae. Soc Neurosci Abstr 18:1400.

Lysakowski A (1996) Morphometric criteria for hair cell types. J Vestib Res [Abstr] S4:S86.

Lysakowski A, Goldberg JM (1997) Regional variations in the cellular and synaptic architecture of the chinchilla cristae. J Comp Neurol 389:419-443.

Mbiene J-P, Favre D, Sans A (1984) The pattern of ciliary development in fetal mouse vestibular receptors. Anat Embryol 170:229-238.

Mbiene J-P, Favre D, Sans A (1988) Early innervation and differentiation of hair cells in the vestibular epithelia of mouse embryos: SEM and TEM study. Anat Embryol 177:331-340.

Nordemar H (1983a) Embryogenesis of the inner ear. II. The late differentiation of the mammalian crista ampullaris in vivo and in vitro. Acta Otolaryngol (Stockh) 96:1-8.

Nordemar H (1983b) Postnatal development of the vestibular sensory epithelium in the mouse. Acta Otolaryngol (Stockh) 96:447-456.

Ohmori H (1984) Studies of ionic currents in the isolated vestibular hair cell of the chick. J Physiol (Lond) 350:561-581.

Perney TM, Marshall J, Martin KA, Hockfield S, Kaczmarek LK (1992) Expression of the mRNAs for the Kv3.1 potassium channel gene in the adult and developing rat brain. J Neurophysiol 68:756-766.

Perozo E, Bezanilla F (1990) Phosphorylation affects voltage gating of the delayed rectifier $\mathrm{K}^{+}$channel by electrostatic interactions. Neuron 5:685-690.

Peterson EH, Cotton JR, Grant JW (1996) Structural variation in ciliary bundles of the posterior semicircular canal: quantitative anatomy and computational analysis. Ann NY Acad Sci 781:85-102.

Raymond J (1987) In vitro differentiation of mouse embryo statoacoustic ganglion and sensory epithelium. Hear Res 28:45-56.

Rennie KJ, Correia MJ (1994) Potassium currents in mammalian and avian isolated type I semicircular canal hair cells. J Neurophysiol 71:317-329.
Rennie KJ, Ricci AJ, Correia MJ (1996) Electrical filtering in gerbil isolated type I semicircular canal hair cells. J Neurophysiol 75:2117-2123.

Reynolds ES (1963) The use of lead citrate at high pH as an electronopaque stain in electron microscopy. J Cell Biol 17:208-212.

Ricci AJ, Rennie KJ, Correia MJ (1996) The delayed rectifier, $\mathrm{I}_{\mathrm{KI}}$, is the major conductance in type I vestibular hair cells across vestibular end organs. Pflügers Arch 432:34-42.

Rubel EW, Oesterle EC, Weisleder P (1991) Hair cell regeneration in the avian inner ear. In: Regeneration of vertebrate sensory receptor cells (Bock GR, Whelan J, eds), pp 77-96. New York: Wiley.

Ruben RJ (1967) Development of the inner ear of the mouse: a radioautographic study of terminal mitoses. Acta Otolaryngol Suppl (Stockh) 220:1-31.

Rüsch A, Eatock RA (1996a) A delayed rectifier conductance in type I hair cells of the mouse utricle. J Neurophysiol 76:995-1004.

Rüsch A, Eatock RA (1996b) Voltage responses of mouse utricular hair cells to injected currents. Ann NY Acad Sci 781:71-84.

Rüsch A, Eatock RA (1997) Sodium currents in hair cells of the mouse utricle. In: Diversity in auditory mechanics (Lewis ER, Long GR, Lyon RF, Steele CR, Narins PM, Hecht-Poinar E, eds), pp 549-555. Singapore: World Scientific.

Sans A, Chat M (1982) Analysis of temporal and spatial patterns of rat vestibular hair cell differentiation by tritiated thymidine radioautography. J Comp Neurol 206:1-8.

Sans A, Dechesne CJ (1987) Afferent nerve ending development and synaptogenesis in the vestibular epithelium of human fetuses. Hear Res 28:65-72.

Sher AE (1971) The embryonic and postnatal development of the inner ear of the mouse. Acta Otolaryngol Suppl (Stockh) 285:5-77.

Sokolowski BHA, Stahl LM, Fuchs PA (1993) Morphological and physiological development of vestibular hair cells in the organ-cultured otocyst of the chick. Dev Biol 155:134-146.

Sugihara I, Furukawa T (1996) Inwardly rectifying currents in hair cells and supporting cells in the goldfish sacculus. J Physiol (Lond) 495:665-679.

Van de Water TR (1984) Developmental mechanisms of mammalian inner ear formation. In: Hearing science (Berlin CI, ed), pp 49-107. San Diego: College-Hill.

Van de Water TR, Anniko M, Nordemar H, Wersäll J (1977) Embryonic development of the sensory cells in macula utriculae of mouse. INSERM (Inst Natl Santé Rech Med) Colloq 68:25-35.

Weisleder P, Rubel EW (1993) Hair cell regeneration after streptomycin toxicity in the avian vestibular epithelium. J Comp Neurol 330:1-14.

Wersäll J (1956) Studies on the structure and innervation of the sensory epithelium of the crista ampullares in the guinea pig. Acta Otolaryngol Suppl (Stockh) 126:1-85.

Wersäll J, Bagger-Sjöbäck D (1974) Morphology of the vestibular sense organ. In: Handbook of sensory physiology. Vestibular system. Basic mechanisms (Kornhuber HH, ed), pp 123-170. New York: Springer.

Wu Y-C, Art JJ, Goodman MB, Fettiplace R (1995) A kinetic description of the calcium-activated potassium channel and its application to electrical tuning of hair cells. Prog Biophys Mol Biol 63:131-158. 